OPEN ACCESS

Edited by:

Kwan-Nang Pang, Institute of Earth Sciences, Academia

Sinica, Taiwan

Reviewed by:

David R. Lentz,

University of New Brunswick

Fredericton, Canada

J. Victor Owen,

Saint Mary's University, Canada

${ }^{*}$ Correspondence: Kenshi Suga

sgkenshi@ntnu.edu.tw

Specialty section: This article was submitted to Petrology,

a section of the journal

Frontiers in Earth Science

Received: 20 January 2020 Accepted: 19 March 2020

Published: 15 May 2020

Citation:

Suga K and Yeh M-W (2020) Secular Variation of Early Cretaceous Granitoids in Kyushu, SW Japan:

The Role of Mélange Rocks as a Possible Magma Source.

Front. Earth Sci. 8:95

doi: 10.3389/feart.2020.00095

\section{Secular Variation of Early Cretaceous Granitoids in Kyushu, SW Japan: The Role of Mélange Rocks as a Possible Magma Source}

\author{
Kenshi Suga* and Meng-Wan Yeh \\ Department of Earth Sciences, National Taiwan Normal University, Taipei, Taiwan
}

The Early Cretaceous volcanic-arc granitic rocks from Kyushu, SW Japan are contemporaneous with the granitic rocks of the Yanshan Orogeny (SE China) along the eastern Eurasian continental margin. The secular geochemical variations of the wholerock major elemental and Sr-Nd isotope data of the Early Cretaceous granitic rocks from Kyushu, SW Japan, as well as the zircon and apatite saturation temperatures, shows distinct changes during the Albian ( 115 to $\sim 100 \mathrm{Ma}$ ) as: (1) the mASI value of the rocks (i.e., Shiraishino granodiorites) decreases below 1, (2) the Sr-Nd isotopic data are relatively constant $\left[{ }^{87} \mathrm{Sr} /{ }^{86} \mathrm{Sr}_{\mathrm{i}}=0.70471\right.$ to $0.70573 ; \varepsilon_{\mathrm{Nd}}(t)=+0.2$ to +1.9$]$ within different rock types including granites, granodiorites, tonalites, and adakitic rocks (i.e., the Shiraishino granodiorites), following the increase of ${ }^{87} \mathrm{Sr} /{ }^{86} \mathrm{Sr}_{i}$ and decrease of $\varepsilon_{\mathrm{Nd}}(t)$ from Berriasian, and (3) higher maximum temperatures at $\sim 105 \mathrm{Ma}$. The secular changes indicate that important geodynamic changes occurred in the arc system of SW Japan as it changed from subduction-accretion during the Jurassic to continental arc during the Early Cretaceous. Thermodynamic partial melting modeling demonstrates that the Albian granitic rocks can be derived from mélange rocks, such as chloriteactinolite schists, at moderate depth and variable redox conditions. It is concluded that the genesis of the Early Cretaceous granitic rocks from Kyushu, SW Japan, may be related to upwelling of the asthenosphere and hot corner flow into the mantle wedge caused by slab rollback, which followed a shallowing of the subduction angle and subsequent flat-slab subduction during the Late Jurassic. The resultant heat induced the partial melting of the mélange rocks that formed on and were transported from the subducted plate interface.

Keywords: granitoids, mélange, arc magma, partial melt, Early Cretaceous, SW Japan, Yanshan orogeny

\section{INTRODUCTION}

Convergent margin magmatism occurred along the eastern Eurasian continental margin during the Late Jurassic to Late Cretaceous as the Paleo-Pacific plate subducted. Magmatism extended from the Korean Peninsula in the north to Vietnam in the south and represents a major period of juvenile crust formation and recycling in East Asia (Xu et al., 2002; Nguyen et al., 2004; Zhou et al., 2006; Kiminami and Imaoka, 2013; Shellnutt et al., 2013; Kim et al., 2016). Alternating periods of crustal 
shortening and extension accompanied by magmatism during the Late Mesozoic are collectively referred to as the Yanshan Orogeny (Wu, 2005; Zhou et al., 2006; Li and Li, 2007; Dong et al., 2018). The Yanshan Orogeny consists of an early period $(\sim 170$ to $\sim 135 \mathrm{Ma})$ of crustal shortening and a late $(\sim 135$ to $\sim 90 \mathrm{Ma})$ period of extension followed by a brief period $(\sim 80 \mathrm{Ma})$ of weak crustal shortening (Dong et al., 2018). The majority of Early Cretaceous magmatic rocks from SE China, NE China, Korea, and SW Japan are compositionally similar to volcanic-arc granites and it appears that their emplacement migrated eastward toward the Eurasia margin over time (Chen and Jahn, 1998; Zhou and Li, 2000; Xu et al., 2002; Zhou et al., 2006; Kiminami and Imaoka, 2013; Kim et al., 2016).

The formation of Late Yanshanian granitic rocks is debated as there are different models proposed for different regions. On the one hand, plutons from SE China are thought to be related to extension-induced melting of mafic igneous protoliths at midlower crustal depths, due to the heat advection resulting from the underplating of basaltic magmas along the active continental margin (Zhou and Li, 2000; Zhou et al., 2006). On the other hand, the Early Cretaceous granitic rocks from the Korean Peninsula and SW Japan are explained by partial melting of lower continental crust, due to slab rollback (Kiminami and Imaoka, 2013; Kim et al., 2016), whereas, for NE China, by interaction of delaminated lower mafic continental crust with an upwelling asthenosphere (Xu et al., 2002; Hou et al., 2007; Lan et al., 2011). The difference in the melting regimes and tectonomagmatic models may be, in part, related to the paleoposition of Korea and Japan relative to China. Although there is along strike subduction, Early Cretaceous magmatism in NE Asia may be related to subduction of the Izanagi plate, whereas in eastern China, it is related to subduction of the Paleo-Pacific plate (Maruyama et al., 1997). Moreover, it is still debated whether the paleogeographic position of Korea and SW Japan belongs to the North China craton or the South China craton (Osanai et al., 1999, 2006; Ishiwatari and Tsujimori, 2003; Ernst et al., 2007; Oh and Kusky, 2007; Omori and Isozaki, 2011; Suga et al., 2017).

The upwelling of hot asthenosphere into the mantle wedge caused by slab rollback may have played a vital role in the formation of Early Cretaceous granitic rocks in NE Asia as this is thought to be the primary process that produces the adakitic rocks of SW Japan (Kamei, 2004; Imaoka et al., 2014; Kim et al., 2016). Alternatively, it is possible that the combination of asthenospheric upwelling and hot corner flow caused by slab rollback may have induced partial melting of mélange rocks, such as chlorite-actinolite schists, producing intermediate to silicic melts (Marschall and Schumacher, 2012; Hao et al., 2016). The Early Cretaceous granitic rocks, including adakitic rocks, in Kyushu, SW Japan, therefore, potentially provide an opportunity to investigate the genesis of granitic rocks related to the combination of asthenospheric upwelling and hot corner flow caused by slab rollback.

In this study, whole rock geochemical data from $\sim 150$ granitic samples across Kyushu, SW Japan, are compiled in order to determine if there is a secular variation in the nature of the plutons and to assess the role subduction-related mélange rocks may play in their origin. Thermodynamic modeling using the program Rhyolite-MELTS is used to evaluate whether partial melting of mélange rocks is either partially or wholly responsible for the genesis of some Early Cretaceous felsic igneous rocks, including the adakitic plutons.

\section{GEOLOGICAL BACKGROUND}

The Japanese Islands comprise a number of subduction-related orogenic belts that were produced beneath the Eurasian continent over more than c. 500 Myr (Maruyama et al., 1997; Isozaki et al., 2010). The geotectonic framework in the inner zone of southwest Japan is made up of, from north to south, the HidaOki, Renge, Akiyoshi, Suo, Maizuru, Ultra-Tamba, Mino-Tanba, and Ryoke belts, with a tectonically downward-younging polarity that resulted from stepwise accretions during the Paleozoic to Mesozoic (Nishimura, 1998; Figure 1). In Kyushu, SW Japan, the Renge, Akiyoshi, Suo, and Ryoke belts occur on the northern side of Usuki-Yatsushiro tectonic line, where Cretaceous igneous rocks are distributed (Figure 1).

Cretaceous plutonic rocks in Kyushu consist mainly of granites, tonalites, and granodiorites with subordinate gabbro and diorites (Figure 1). They intruded metamorphic rocks of the Renge, Suo, Ryoke, and Higo belts, and sedimentary rocks of the Cretaceous Kanmon Group. Cretaceous andesites and dacite occur in and around Kyushu (Imaoka et al., 1993; Matsuura, 1998; Owada et al., 1999).

Published age dates of the granitic rocks using various methods (K-Ar, Rb-Sr, Sm-Nd, CHIME, U-Pb) on whole rock and minerals range from 143 to $75 \mathrm{Ma}$, whereas the mafic rocks yielded ages $(\mathrm{K}-\mathrm{Ar}, \mathrm{Rb}-\mathrm{Sr}, \mathrm{U}-\mathrm{Pb})$ that are comparatively more restricted and were emplaced from 123 to $97 \mathrm{Ma}$ (Hattori and Shibata, 1982; Sasada, 1987; Osanai et al., 1993; Nakajima et al., 1995; Kamei et al., 1997, 2000, 2004; Matsuura, 1998; Hamamoto et al., 1999; Owada et al., 1999; Takagi et al., 2000, 2007; Sakashima et al., 2003; Nishimura et al., 2004; Fujii et al., 2008; Kouchi et al., 2011; Miyoshi et al., 2011; Adachi et al., 2012; Tiepolo et al., 2012; Miyazaki et al., 2018). In comparison, the dacite and andesite yielded K-Ar mineral ages of $107 \pm 3 \mathrm{Ma}$ (Imaoka et al., 1993) and from 110 to $102 \mathrm{Ma}$ (Imaoka et al., 1993; Matsuura, 1998; Owada et al., 1999), respectively.

The Nagasaki high- $P$ metamorphic rocks are distributed in western Kyushu (Figure 1). The rocks are a western extension of the high- $P$ Sanbagawa metamorphic rocks of southwest Japan (Faure et al., 1988; Nishimura et al., 2004), which are the higher $P / T$ members of a Cretaceous paired metamorphic belt that joins the high- $T$ metamorphic rocks of the Ryoke plutono-metamorphic belt along the Median Tectonic Line. Toward the west, the Cretaceous plutonic rocks and related high- $T$ metamorphic rocks, including the Higo high$T$ metamorphic rocks, are distributed throughout central to northern Kyushu.

The Nishisonogi unit of the Nagasaki metamorphic rocks forms a Late Cretaceous subduction complex that consists mainly of epidote-blueschist facies pelitic, psammitic, and mafic schists with minor serpentinite (Nishiyama, 1990; Mori et al., 2014). The serpentinite, which is in tectonic contact with the schists, 


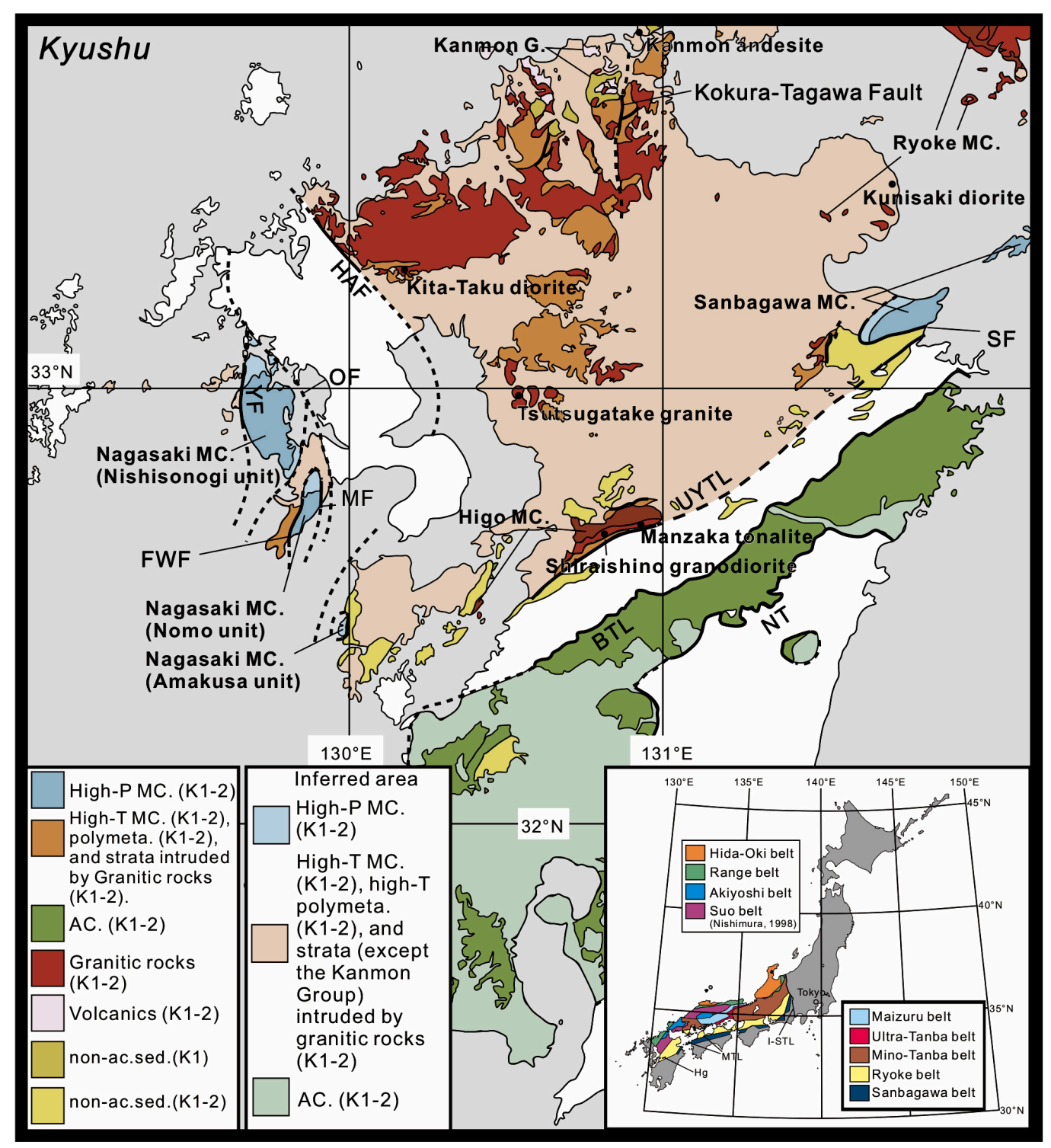

FIGURE 1 | Distribution of Cretaceous accretionary complex, metamorphic complex, plutonic rocks, volcanic rocks, and non-accretionary sedimentary rocks in Kyushu, SW Japan [modified from Miyazaki et al. (2016) based on the seamless geological map of Japan (1:200,000), Geological Survey of Japan, https://gbank.gsj.jp/seamless/index_en.html] with solid circle indicating the locality of granitic rock samples of which the thermodynamic modeling was modeled in this study. UYTL, Usuki-Yatsushiro Tectonic Line; BTL, Butsuzo Tectonic Line; SF, Sashu Fault; HAF, Hatashima-Ariake Fault; FWF, Fukabori-Wakimisaki Fault; OF, Omurawan-Amakusa Fault; YF, Yobikonoseto Fault; MF, Mogi Fault; NT, Nobeoka Thrust; MC, Metamorphic Complex; AC, Accretionary Complex; polymeta, polymetamorphic rocks; non-ac.sed., non-accretionary sedimentary rocks; K1-2, Early-Late Cretaceous; K1, Early Cretaceous. Inset-map showing a geotectonic map of SW Japan (modified form Nishimura, 1998 with permission). MTL, Median Tectonic Line; I-STL, Itoigawa-Shizuoka Tectonic Line; Hg, Higo belt.

occurs as pod-like bodies of $<150 \mathrm{~m}$ in diameter and ultramafic melanges of $<350 \mathrm{~m}$ in thickness (Mori et al., 2014). The ultramafic melanges contain tectonic blocks of metagabbro, mafic schist, pelitic schist, and albitite in a matrix of chlorite-actinolite schist, talc schist, and schistose serpentinite (Nishiyama, 1989, 1990). Small blocks ( $<5 \mathrm{~m}$ in diameter) of jadeitite, omphacitite, rodingite, and zoisitite are found locally (Nishiyama, 1978; Shigeno et al., 2005, 2012a,b; Mori et al., 2011). The mineral assemblages of the schists suggest the peak metamorphic $P-T$ conditions of $8 \mathrm{kbar}$ and $400^{\circ} \mathrm{C}$ (Mori et al., 2014). The peak metamorphic conditions for the jadeitites were estimated to be $P>13 \mathrm{kbar}$ and $T>400^{\circ} \mathrm{C}$ (Shigeno et al., 2005).

Metamorphic age data $\left(\mathrm{K}-\mathrm{Ar},{ }^{40} \mathrm{Ar} /{ }^{39} \mathrm{Ar}, \mathrm{U}-\mathrm{Pb}\right)$ from the pelitic and psammitic schists range from 85 to $60 \mathrm{Ma}$ (Hattori and Shibata, 1982; Faure et al., 1988; Miyazaki et al., 2019), 85$65 \mathrm{Ma}\left({ }^{40} \mathrm{Ar} /{ }^{39} \mathrm{Ar}, \mathrm{U}-\mathrm{Pb}\right)$ for the jadeitites (Mori et al., 2007, 2011; Yui et al., 2012), and 108-105 Ma (U-Pb) for the rodingites (Fukuyama et al., 2014). The youngest detrital zircon ages and metamorphism duration were estimated to be 97-79 Ma and 10 to 20 Myr, respectively (Miyazaki et al., 2019). 


\section{A}
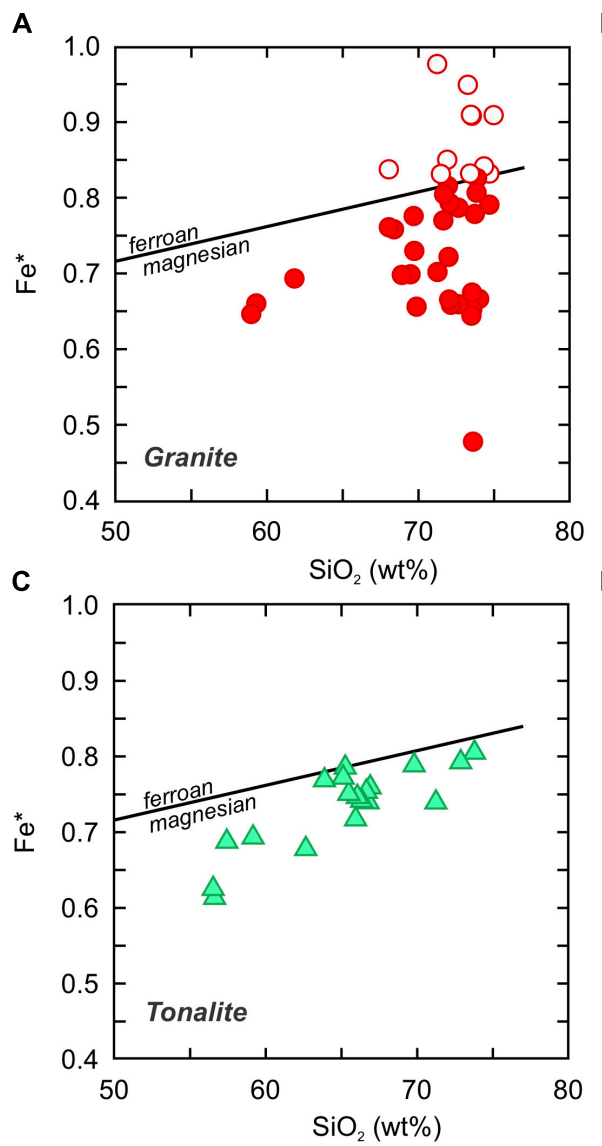

B

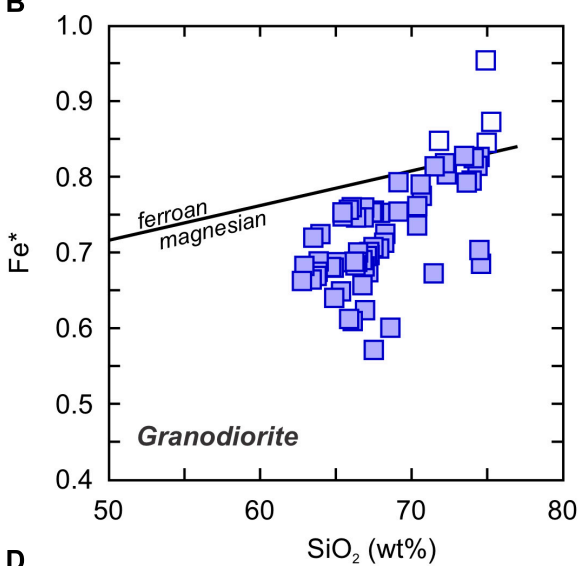

D

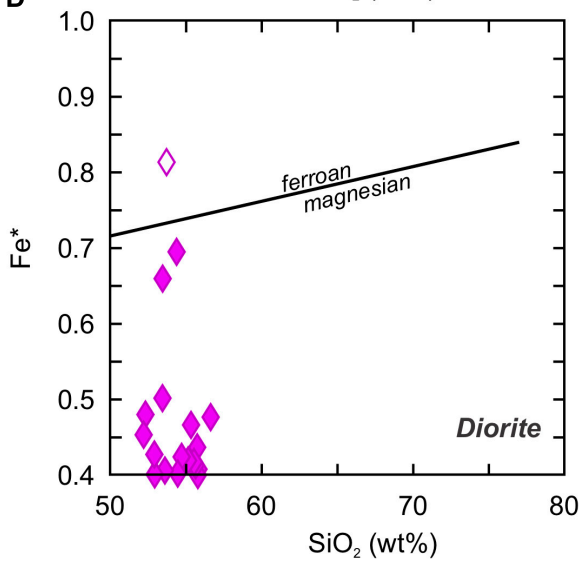

FIGURE 2 | Division of the Cretaceous (A) granites, (B) granodiorites, (C) tonalites, and (D) diorites from Kyushu into ferroan and magnesian compositions using the $\mathrm{Fe}^{\star}[\mathrm{FeOt} /(\mathrm{FeOt}+\mathrm{MgO})]$ vs. $\mathrm{SiO}_{2}$ (wt\%) discrimination of Frost et al. (2001).

\section{GEOCHEMICAL CHARACTERISTICS OF CRETACEOUS GRANITOIDS IN KYUSHU, SW JAPAN}

Whole-rock major elemental data published for 148 samples of granitic rocks from Kyushu were compiled (Supplementary Table S1) and plotted using the geochemical classification diagrams of granitic rocks reported by Frost et al. (2001; Figures 2, 3) and Harker diagrams (Figure 4). The granites $(n=40)$ are peraluminous to metaluminous, ferroan to magnesian $\left(\mathrm{Fe}^{*}=0.48-0.98\right)$, and alkalic to calcic in composition with $\mathrm{Mg} \#$ ranging from 4 to 66 and $\mathrm{K}_{2} \mathrm{O} / \mathrm{Na}_{2} \mathrm{O}$ ratios of $0.5-$ 1.6. The rocks have high $\mathrm{SiO}_{2}$ contents as all but 3 samples have $\mathrm{SiO}_{2}$ from 68.1 to $75.0 \mathrm{wt} . \%$. The granodiorites $(n=65)$ are peraluminous to metaluminous, ferroan to magnesian $\left(\mathrm{Fe}^{*}=0.57-0.95\right)$, and calc-alkalic to calcic in composition with $\mathrm{Mg}$ \# ranging from 8 to 57 and $\mathrm{K}_{2} \mathrm{O} / \mathrm{Na}_{2} \mathrm{O}$ ratios of $0.2-1.5$. The $\mathrm{SiO}_{2}$ contents range from 62.8 to $75.3 \mathrm{wt} . \%$. The tonalites $(n=19)$ are peraluminous to metaluminous, magnesian $\left(\mathrm{Fe}^{*}=0.61-0.80\right)$, and calc-alkalic to calcic in composition with $\mathrm{Mg \#} \mathrm{ranging} \mathrm{from}$ 30 to 53 and $\mathrm{K}_{2} \mathrm{O} / \mathrm{Na}_{2} \mathrm{O}$ ratios of $0.3-1.1$. The $\mathrm{SiO}_{2}$ contents range from 56.5 to $73.8 \mathrm{wt} . \%$. The granite, granodiorite, and tonalite plutons have similar negative trends of $\mathrm{TiO}_{2}, \mathrm{Al}_{2} \mathrm{O}_{3}$,
$\mathrm{CaO}$, and $\mathrm{Mg \#}$, and positive trends of $\mathrm{Na}_{2} \mathrm{O}+\mathrm{K}_{2} \mathrm{O}$, against $\mathrm{SiO}_{2}$ (Figure 4). They also have similar loss on ignition (LOI) values of $0.0-1.8 \mathrm{wt} . \%$.

By comparison, the diorites $(n=24)$, for the exception of 3 samples, are metaluminous, magnesian $\left(\mathrm{Fe}^{*}=0.36-0.50\right)$, and calc-alkalic to calcic in composition (Figures 2-4). They have higher $\mathrm{Mg} \#$ ranging from 64 to 76 and lower $\mathrm{SiO}_{2}$ contents of 52.2-59.4 wt.\%, and have similar $\mathrm{K}_{2} \mathrm{O} / \mathrm{Na}_{2} \mathrm{O}$ ratios of $0.3-0.9$, compared to the granites, granodiorites, and tonalites. There is a weak positive trend of $\mathrm{Na}_{2} \mathrm{O}+\mathrm{K}_{2} \mathrm{O}$ against $\mathrm{SiO}_{2}$. The trend line is extrapolated into the corresponding lines for the granites, granodiolites, and tonalites. LOI contents are $0.5-2.1 \mathrm{wt} . \%$, which are similar to those of the granites, granodiorites, and tonalites.

Some or all trace elemental data were reported from 127 samples across all rock types. The trace element concentrations of the granites, granodiorites, and tonalites show broad similarities across all elements, but the diorites are somewhat unique. The concentration of transition metals $(\mathrm{Sc} \leq 12 \mathrm{ppm}, \mathrm{V}=2$ to $178 \mathrm{ppm}, \mathrm{Cr} \leq 56 \mathrm{ppm}, \mathrm{Ni} \leq 22 \mathrm{ppm}, \mathrm{Cu}=3$ to $182 \mathrm{ppm}$, and $\mathrm{Zn}=4$ to $117 \mathrm{ppm}$ ) for the granites, tonalites, and granodiorites are similar. In contrast, the diorites have comparatively higher concentrations of V (125-231 ppm), Cr (5-1544 ppm), and $\mathrm{Ni}$ (10-259 ppm), but similar concentrations of $\mathrm{Cu}(18-116 \mathrm{ppm})$ 

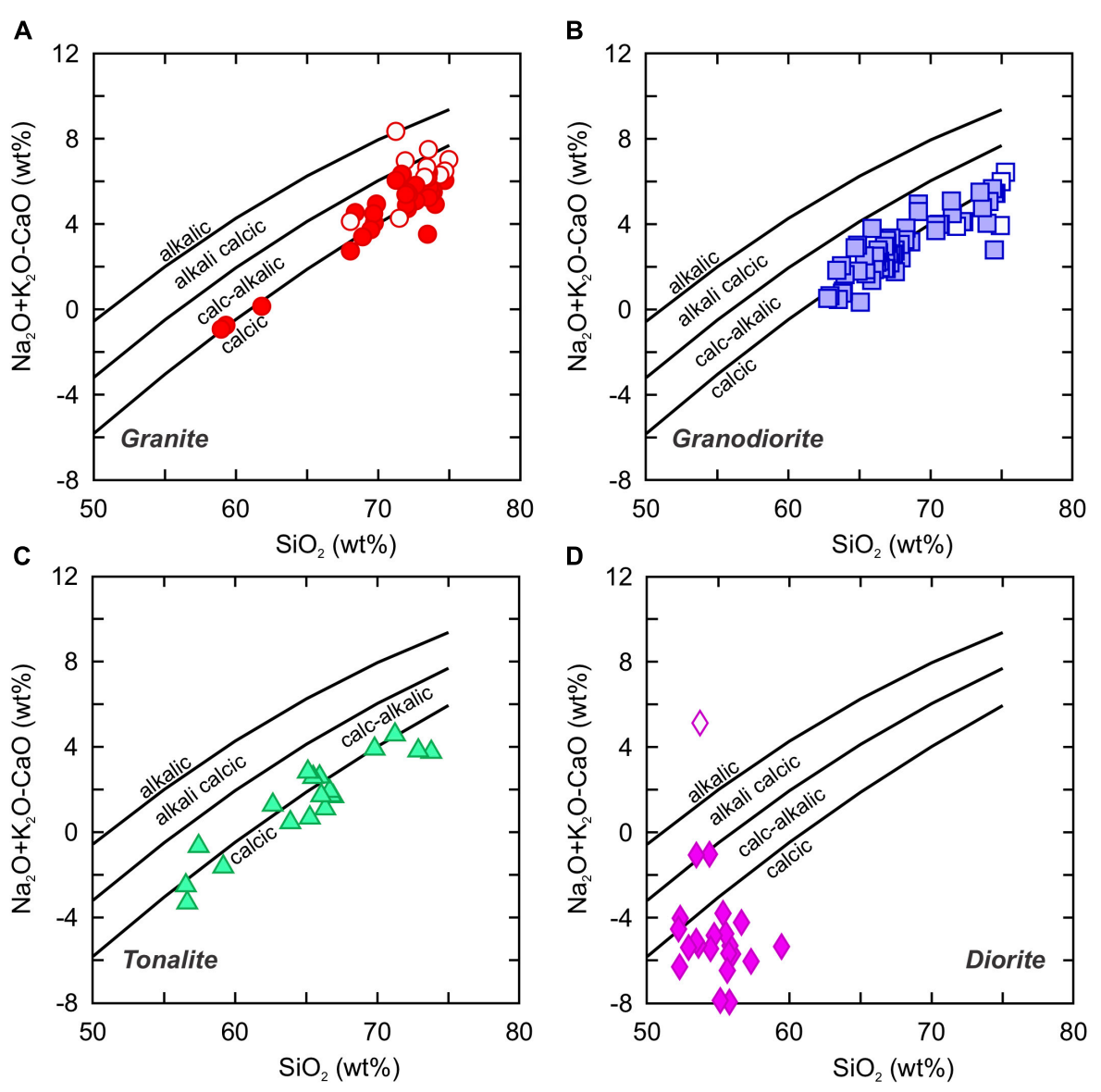

FIGURE 3 | Modified alkali-lime index $\left(\mathrm{Na}_{2} \mathrm{O}+\mathrm{K}_{2} \mathrm{O}-\mathrm{CaO}\right.$ wt\%) vs. $\mathrm{SiO}_{2}$ (wt\%) of the Cretaceous (A) granites, (B) granodiorites, (C) tonalites, and (D) diorites from Kyushu (Frost et al., 2001). Symbols as in Figure 2.

and $\mathrm{Zn}$ (57-110 ppm). The large ion lithophile elements (Rb, Sr, and $\mathrm{Ba}$ ) show more chemical variability in all rock types, but the diorites tend to have lower concentrations of $\mathrm{Rb}$ (10-74 ppm) and $\mathrm{Ba}$ (52-405 ppm) and similar Sr (75 to $864 \mathrm{ppm}$ ) compared to the granites, tonalites, and granodiorites $(\mathrm{Rb}=38-186 \mathrm{ppm}$, $\mathrm{Sr}=117-859 \mathrm{ppm}, \mathrm{Ba}=214-1142 \mathrm{ppm})$. The concentrations of $\mathrm{Y}$ and $\mathrm{Nb}$ across all rock types are generally similar $(\mathrm{Y}=5-$ $39 \mathrm{ppm}, \mathrm{Nb}=4-24 \mathrm{ppm}$ ), although the diorites tend to have lower concentrations of $\mathrm{Zr}$ (16-102 ppm) and the granites tend to have higher concentrations of Th (3-26 ppm), compared to other rock types $(\mathrm{Zr}=47-218 \mathrm{ppm}, \mathrm{Th}=0.9-23 \mathrm{ppm})$.

The primitive mantle normalization patterns show enrichment of the less incompatible elements over the incompatible elements but they also have prominent depletions of $\mathrm{Ba}, \mathrm{Nb}$, and Ti (Figure 5). The granodiorites have a subgroup of Hf depleted rocks but it is not certain if it is unique as Hf data was not reported for the diorites. The chondrite-normalized rare-earth element patterns of the granodiorites and tonalites show similar light rareearth element (LREE) enrichment and tend to have high $\mathrm{La} / \mathrm{Yb}_{\mathrm{N}}$ ratios (5.6 to 35.4), whereas the diorites have moderately to slight LREE $\left(\mathrm{La} / \mathrm{Yb}_{\mathrm{N}}<5\right)$ enrichment (Figure 6). Rare earth elemental data are not available for the granites. The rocks generally do not display prominent depletion of Eu as the tonalites, diorites and most of the granodiorites (all but 4 ) have Eu/Eu* values $\geq 0.8$. The relatively high $\mathrm{Eu} / \mathrm{Eu}^{*}$ values indicate that the rocks probably did not experience significant plagioclase fractionation.

Strontium and $\mathrm{Nd}$ isotopic data are only available for the granites, granodiorites, and tonalites (Supplementary Table S2). There are more samples with $\mathrm{Sr}$ isotopes (123) reported than $\mathrm{Nd}$ isotopes (48). Moreover, the $\mathrm{Sr}$ isotopes cover nearly the entire Cretaceous $(\sim 145$ to $\sim 85 \mathrm{Ma})$, whereas there is an age gap $(\sim 140$ to $\sim 120 \mathrm{Ma})$ within samples that have $\mathrm{Nd}$ isotope data. The initial $\mathrm{Sr}$ isotope ratios $\left({ }^{87} \mathrm{Sr} /{ }^{86} \mathrm{Sr}_{\mathrm{i}}\right)$ of granites (0.70404 to 0.70654$)$, granodiorites $(0.70471$ to $0.70573)$, and tonalites ( 0.70430 to 0.70529$)$ are similar and have relatively restricted ranges, although there are two outliers (0.70302 and 0.70620) within the granodiorites. The $\mathrm{Nd}$ isotopes, as expressed by the $\varepsilon_{\mathrm{Nd}}(t)$ notation, show distinct negative values for the granites $\left[\varepsilon_{\mathrm{Nd}}(t)=-4.7\right.$ to +1.0$]$ compared to the granodiorites $\left[\varepsilon_{\mathrm{Nd}}(t)=+0.5\right.$ to +1.6$]$ and tonalites $\left[\varepsilon_{\mathrm{Nd}}(t)=+0.2\right.$ to +3.1$]$. The $\mathrm{Nd}$ depleted mantle model ages of the granites are $0.7-1.4 \mathrm{Ga}$, which are older than those of the granodiorites $(0.6-1.1 \mathrm{Ga})$ and tonalites $(0.8-1.2 \mathrm{Ga})$. 

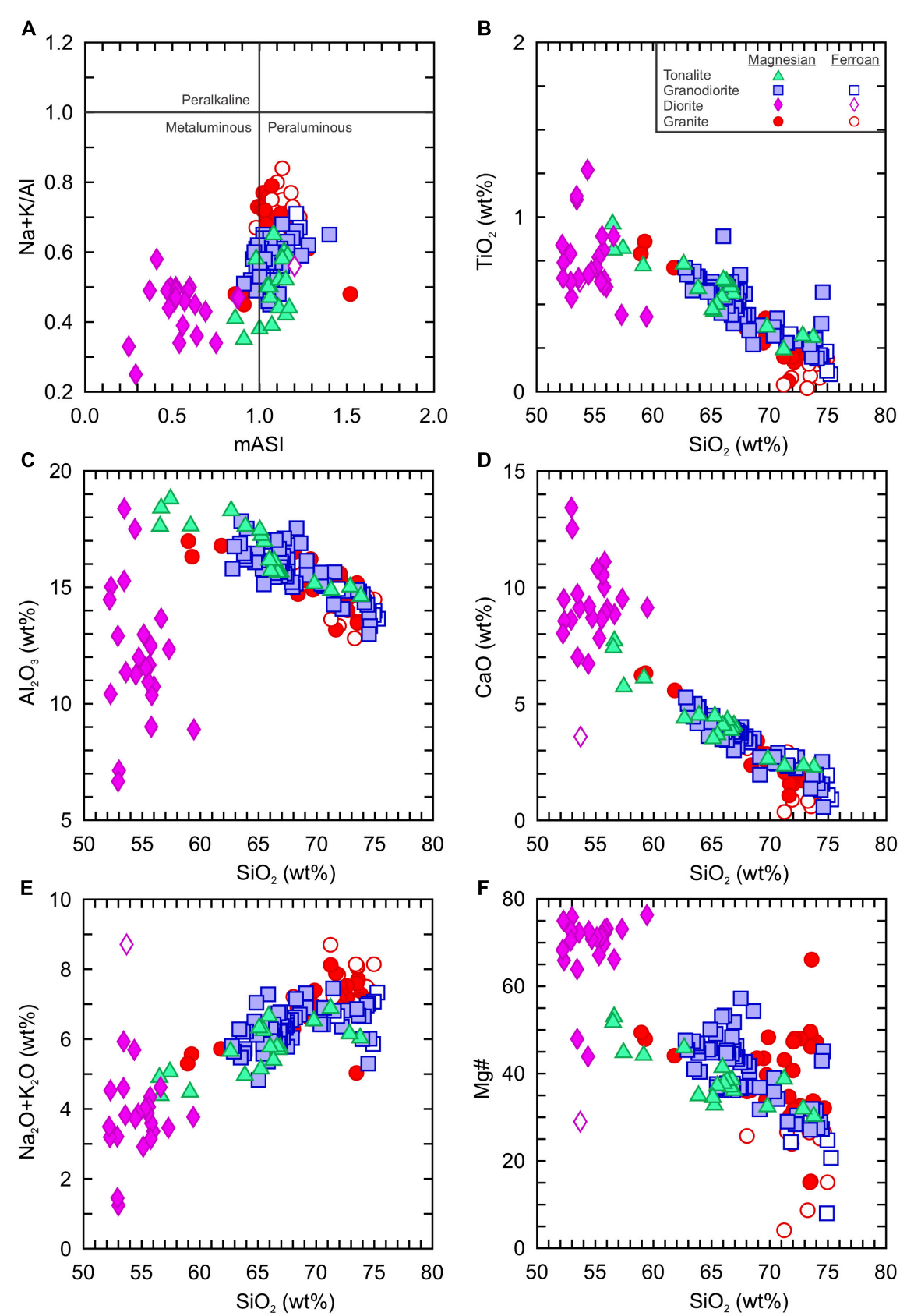

FIGURE 4 | Major element variation of the Cretaceous granites, granodiorites, tonalites, and diorites from Kyushu. (A) Alumina saturation index [mASI = molecular $\mathrm{Al} /(\mathrm{Ca}-1.67 \mathrm{P}+\mathrm{Na}+\mathrm{K})]$ vs. alkali-alumina ratio [molecular $(\mathrm{Na}+\mathrm{K}) / \mathrm{Al}]$. (B) $\mathrm{TiO}_{2}$ (wt\%) vs. $\mathrm{SiO}_{2}$ (wt\%). (C) $\mathrm{Al}_{2} \mathrm{O}_{3}$ (wt\%) vs. $\mathrm{SiO} 2$ (wt\%), (D) $\mathrm{CaO}$ (wt\%) vs. $\mathrm{SiO} 2$ (wt\%). (E) $\mathrm{Na}_{2} \mathrm{O}+\mathrm{K}_{2} \mathrm{O}$ (wt\%) vs. $\mathrm{SiO}_{2}$ (wt\%). (F) Mg\# [molecular Mg/(Mg + Fe) $\left.)^{*} 100\right]$ vs. $\mathrm{SiO}_{2}$ (wt\%). The division of rocks into magnesian and ferroan is plotted in Figure 2.

\section{DISCUSSION}

\section{Petrogenesis of the Early Cretaceous Granitic Rocks in Kyushu, SW Japan Tectonomagmatic Classification}

According to the classification scheme of Frost et al. (2001), the Early Cretaceous granitic rocks from Kyushu, are primarily magnesian, peraluminous to metaluminous, calc-alkalic to calcic in composition (Figures 2-4). Rocks of this composition are considered to be most commonly associated with subductionzone settings. There are some rocks in the data set that are ferroan but they are also highly silicic $\left(\mathrm{SiO}_{2}>72\right.$ wt.\%). Magnesian and ferroan rocks tend to overlap at highly silicic compositions within cogenetic rock suites due to chemical differentiation as intermediate magnesian magmas eventually become ferroan after 


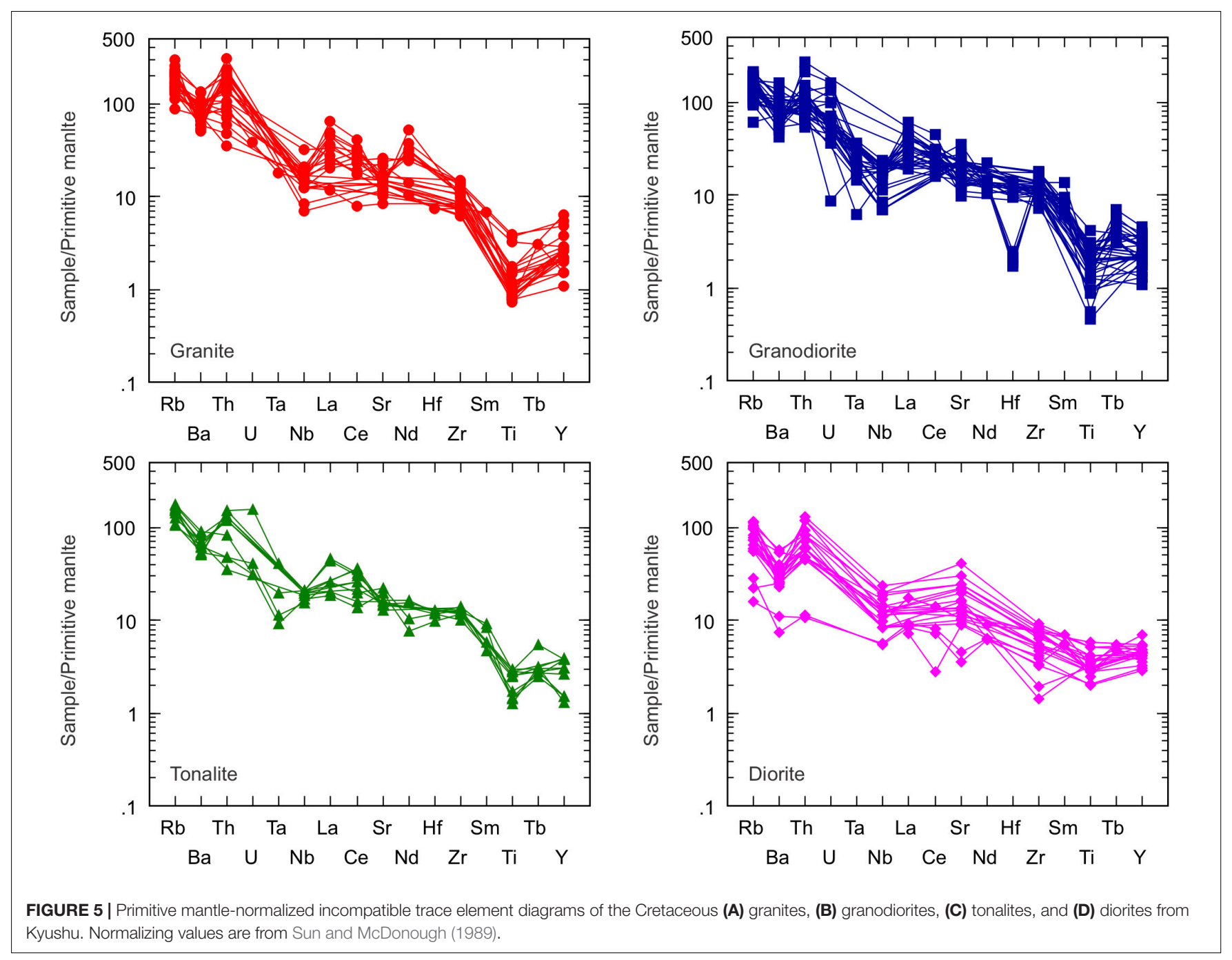

extensive fractional crystallization (Frost et al., 2001). Given that the ferroan rocks in this study are highly silicic and that they fall along the same negative or positive trends of $\mathrm{TiO}_{2}, \mathrm{Al}_{2} \mathrm{O}_{3}$, $\mathrm{CaO}, \mathrm{Mg \#}$, and $\mathrm{Na}_{2} \mathrm{O}+\mathrm{K}_{2} \mathrm{O}$ against $\mathrm{SiO}_{2}$ as the magnesian granitic rocks, they are likely the most evolved compositions of an original magnesian parental magma (Figure 4). The trace element compositions of all samples fall unambiguously within the volcanic-arc/I-type granite field of the $\mathrm{Y}+\mathrm{Nb}-$ $\mathrm{Rb}$ discrimination diagram (Pearce et al., 1984; Christiansen and Keith, 1996) (Figure 7). Moreover, the results indicate that the chemical differentiation trends identified in some of the plutons did not have a significant effect on their $\mathrm{Y}, \mathrm{Nb}$, and $\mathrm{Rb}$ concentrations and thus did not cause 'elemental drift' across the field boundaries (Forster et al., 1997). In other words, the major and trace elemental compositions are mutually supportive of each other, and consistent with the fact that the Japanese Islands comprise a number of subduction-related orogenic belts over more than c. 500 Myr (Maruyama et al., 1997; Isozaki et al., 2010). Thus, there is little doubt that the Early Cretaceous granitic rocks of Kyushu were exclusively emplaced at a volcanic-arc setting.

\section{Secular Compositional and Temperature Variations}

The whole-rock major elemental and $\mathrm{Sr}-\mathrm{Nd}$ isotope data, as well as zircon $\left(T_{\mathrm{Zrc}}\right)$ and apatite $\left(T_{\mathrm{Apt}}\right)$ saturation temperatures, of the granitic rocks are plotted against time $(\mathrm{Ma})$, in order to evaluate the secular compositional and temperature variations during the Cretaceous (Figures 8, 9 and Supplementary Tables S1, S2). The ages of the rocks are reported from high closure temperature minerals ( $\mathrm{U}-\mathrm{Pb}$ zircon, $\mathrm{Rb}-\mathrm{Sr}$ whole-rock isochoron, $\mathrm{K}-\mathrm{Ar}$ hornblende) and are interpreted to be crystallization ages. The zircon $\left(T_{\mathrm{Zrc}}\right)$ and apatite $\left(T_{\mathrm{Apt}}\right)$ saturation temperatures were calculated using the whole rock major and trace element data available for the granitic rocks (Harrison and Watson, 1984; Boehnke et al., 2013).

There is clear secular variation in the major element compositions (Figure 8). The most distinct major element change is the decrease in the alumina saturation index (mASI) value at $\sim 105$ Ma (i.e., Shiraishino granodiorites). All other intrusions have near constant mASI values of $\sim 1.1$ to $\sim 1.2$, whereas the Shiraishino granodiorites have a wide range but drop below 1 and become metaluminous (Figure 8A). In fact the Shiraishino 

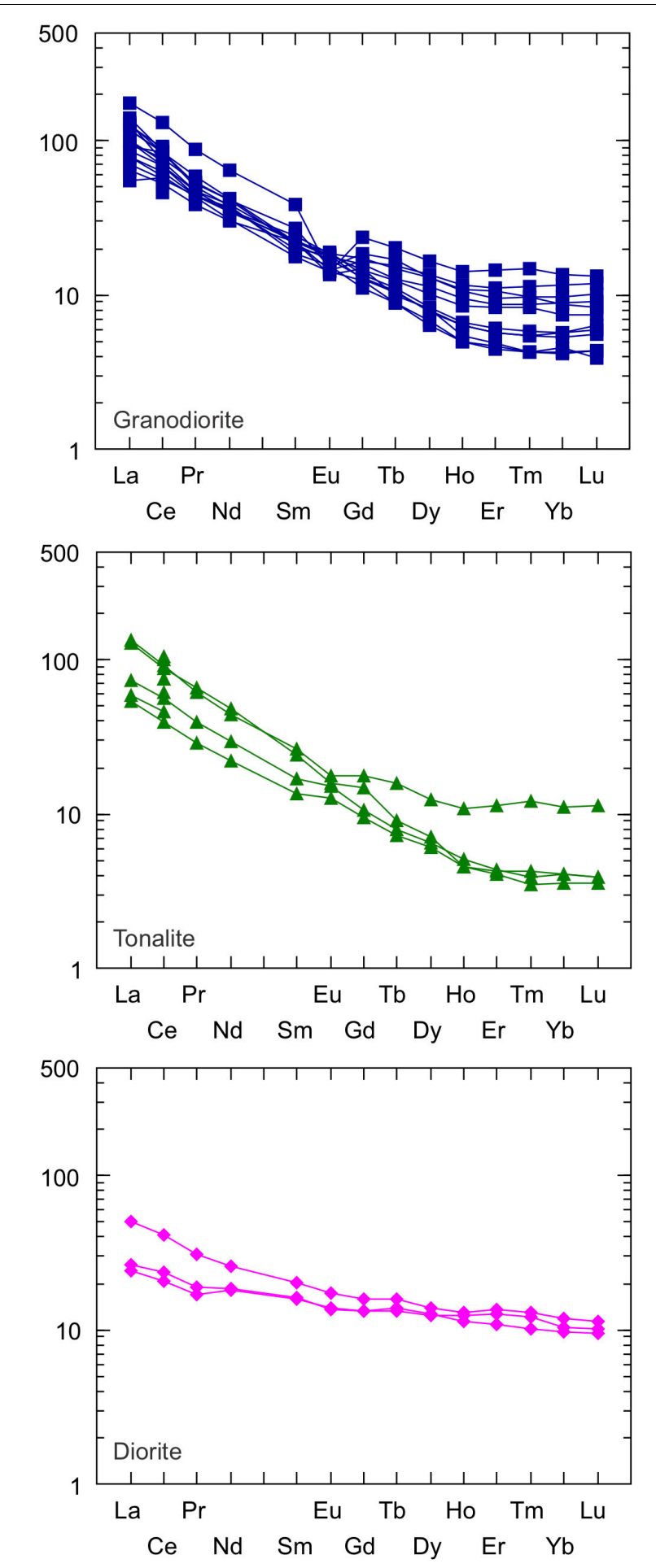

FIGURE 6 | Chondrite-normalized rare earth element patterns of the Cretaceous (A) granodiorites, (B) tonalites, and (C) diorites from Kyushu. Chondrite values are from Sun and McDonough (1989).

granodiorite is the most distinct intrusion as it has high $\mathrm{TiO}_{2}$ $\left(\sim 0.66\right.$ wt.\%) and low $\mathrm{SiO}_{2}(\sim 63.8$ wt.\%) contents and low $\mathrm{K}_{2} \mathrm{O} / \mathrm{Na}_{2} \mathrm{O}$ ratios $(\sim 0.3)$ compared to the other granitic rocks.
However, in spite of the Shiraishino granodiorite, the overall trends show an increase in the $\mathrm{Mg} \#$ and $\mathrm{TiO}_{2}$ and $\mathrm{Al}_{2} \mathrm{O}_{3}$ contents and a decrease in the $\mathrm{K}_{2} \mathrm{O} / \mathrm{Na}_{2} \mathrm{O}$ ratio and $\mathrm{SiO}_{2}$ over time (Figures 8B-F).

The $\mathrm{Sr}-\mathrm{Nd}$ isotopes show two secular trends (Figures 9A,B). There are overall trends for both $\mathrm{Sr}$ and $\mathrm{Nd}$, but they both show changes during the Albian $(\sim 115$ to $\sim 105 \mathrm{Ma})$. The ${ }^{87} \mathrm{Sr} /{ }^{86} \mathrm{Sr}_{\mathrm{i}}$ ratio increases from the Early Cretaceous to the Late Cretaceous, which is mirrored by an overall negative trend in the $\varepsilon_{\mathrm{Nd}}(t)$ values. However, between $\sim 115$ and $\sim 105 \mathrm{Ma}$ it is clear that the ${ }^{87} \mathrm{Sr} /{ }^{86} \mathrm{Sr}_{\mathrm{i}}$ ratio flattens and becomes relatively constant $(\sim 0.7047$ to $\sim 0.7057)$ until it increases $(\sim 0.7065)$ after $105 \mathrm{Ma}$ and then drops $(\sim 0.7051)$ at $\sim 90 \mathrm{Ma}$. Although there is less $\mathrm{Nd}$ isotopic data, a similar pattern as the $\mathrm{Sr}$ isotopes is observed at $\sim 115$ to $\sim 105 \mathrm{Ma}$. The $\varepsilon_{\mathrm{Nd}}(t)$ values of the tonalites, granodiorites and some granites are constant $(\sim+0.2$ to $\sim+1.9)$ before dropping to the lowest values $(-4.7)$ at $\sim 95 \mathrm{Ma}$ and increasing again $(+0.4)$ at $\sim 85 \mathrm{Ma}$. Unlike the major elements where most of the compositional variation at $\sim 105 \mathrm{Ma}$ is attributed to the Shiraishino granodiorites, the isotopic consistency between 115 and $105 \mathrm{Ma}$ occurs within different rock types, implying a relatively uniform source for the Albian rocks. After $\sim 105$ $\mathrm{Ma}$, the increase of the ${ }^{87} \mathrm{Sr} /{ }^{86} \mathrm{Sr}_{\mathrm{i}}$ ratio and decrease of the $\varepsilon_{\mathrm{Nd}}(t)$ values suggests a greater contribution of less radiogenic material was involved in the origin of the granites. It could be that these primitive magmas experienced crustal contamination during emplacement; or that the granites were derived by partial melting of the crust; or the source became more enriched due to an increase in subducted sediment into the mantle wedge. It would seem the first two options are more likely as the $\mathrm{Sr}$ and $\mathrm{Nd}$ isotopic values after $95 \mathrm{Ma}$ return to the values observed during the Albian and some of the granites have higher $\mathrm{Th} / \mathrm{Nb}_{\mathrm{PM}}$ values $(>20)$ (Figure 10).

The calculated $T_{\mathrm{Zrc}}$ and $T_{\mathrm{Apt}}$ for the granites, granodiorites, and tonalites are similar: $T_{\mathrm{Zrc}}=653-740^{\circ} \mathrm{C}$ and $T_{\mathrm{Apt}}=806-$ $927^{\circ} \mathrm{C}$ for the granites, $T_{Z r c}=666-756^{\circ} \mathrm{C}$ and $T_{\mathrm{Apt}}=803-$ $1022^{\circ} \mathrm{C}$ for the granodiorites, $T_{\mathrm{Zrc}}=674-739^{\circ} \mathrm{C}$ and $T_{\mathrm{Apt}}=779-$ $943^{\circ} \mathrm{C}$ for the tonalites. The diorites did not yield meaningful $T_{\mathrm{Zrc}}$ values, because their $\mathrm{M}$ values were outside $(>1.9)$ of the experimental range (Miller et al., 2003), but $T_{\mathrm{Apt}}\left(584-896^{\circ} \mathrm{C}\right)$ estimates are the lowest of all rock types. The estimates of $T_{\mathrm{Zrc}}$ for each rock type are lower than those of $T_{\mathrm{Apt}}$, implying the magma sources were undersaturated in $\mathrm{Zr}$ during partial melting and crystallization. In other words, the estimates of $T_{\text {Apt }}$ represent the maximum temperatures experienced by the granitic rocks, whereas, for $T_{\mathrm{Zrc}}$, are probably the minimum temperatures.

Over this time interval, the $T_{\mathrm{Zrc}}$ and $T_{\mathrm{Apt}}$ estimates of the granites, granodiorites, and tonalites increased from $T_{\mathrm{Zrc}}=\sim 660^{\circ} \mathrm{C}$ and $T_{\mathrm{Apt}}=\sim 810^{\circ} \mathrm{C}$ at $135 \mathrm{Ma}$ and reached a peak of $T_{\mathrm{Zrc}}=\sim 750^{\circ} \mathrm{C}$ and $T_{\mathrm{Apt}}=\sim 960^{\circ} \mathrm{C}$ at $\sim 105 \mathrm{Ma}$. This is followed by lower $T_{\text {Apt }}$ temperatures to $840^{\circ} \mathrm{C}$ at $81 \mathrm{Ma}$. Both the higher peaks of $T_{\mathrm{Zrc}}$ and $T_{\mathrm{Apt}}$ estimates are recorded in the granodiorites (i.e., Shiraishino granodiorite).

The secular variations observed within the whole-rock major elemental and $\mathrm{Sr}-\mathrm{Nd}$ isotope data, and zircon $\left(T_{\mathrm{Zrc}}\right)$ and apatite $\left(T_{\text {Apt }}\right)$ saturation temperatures reveal important geodynamic changes in the development of the Cretaceous arc system of 

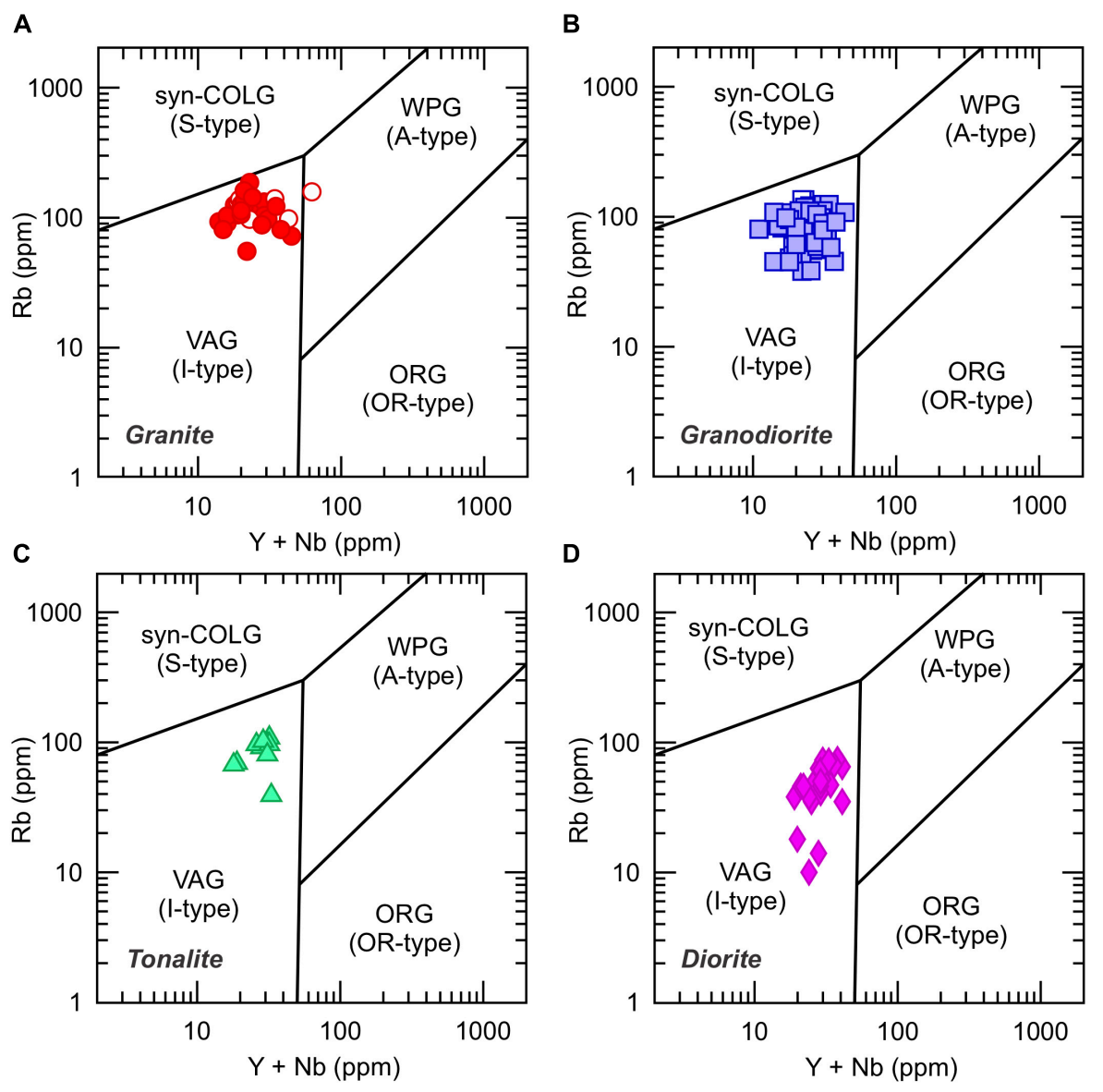

FIGURE 7 | Tectonomagmatic discrimination of the Cretaceous (A) granites, (B) granodiorites, (C) tonalites, and (D) diorites from Kyushu using Rb (ppm) vs. Y + Nb (ppm) criteria of Pearce et al. (1984) enhanced with Christiansen and Keith (1996). Symbols as in Figure 2. VAG, volcanic arc granites; ORG, ocean ridge granites; syn-COLG, syn-collisional granites; WPG, within-plate granites; OR, ocean ridge.

SW Japan. The rocks are principally magnesian and calc-alkalic, and have relatively high $\mathrm{Eu} / \mathrm{Eu}^{*}$ values $(\geq 0.8)$. The magnesian nature of the rocks implies that their parental magmas were likely oxidized as this would lead to early crystallization of magnetite or Ti-rich magnetite and a relatively high Mg\# (Osborn, 1959; Buddington and Lindsley, 1964). Moreover, the rocks are calcalkalic to calcic and have relatively high $\mathrm{Eu} / \mathrm{Eu}^{*}$ values which is likely a consequence of water-rich magma systems as plagioclase crystallization is suppressed under hydrous conditions (Arculus, 2003). In this regard, the relative uniformity of the rocks is supportive of a long term volcanic-arc setting as oxidizing and water-rich conditions are expected at subduction zones (Arculus, 2003; Plank et al., 2013).

It is clear that the Albian rocks, and perhaps the older (Valanginian) and youngest (Coniacian) rocks, are derived from a relatively uniform source as they have similar ${ }^{87} \mathrm{Sr} /{ }^{86} \mathrm{Sr}_{\mathrm{i}}$ ratios and $\varepsilon_{\mathrm{Nd}}(t)$ values, as described above. The two exceptions are the oldest rocks (Berriasian) that are the most radiogenic and the $\sim 95 \mathrm{Ma}$ rocks (Cenomanian) that are the most unradiogenic rocks. As mentioned previously, the $\mathrm{Sr}-\mathrm{Nd}$ isotopic data of the $\sim 95 \mathrm{Ma}$ rocks may reflect crustal contamination during emplacement, or partial melting of the crust. The fact that the Albian rocks are all less radiogenic than the Berriasian-Valanginian rocks in spite of their different rock types (granodiorite, tonalite, granite) indicates they are probably derived from a source that became slightly less radiogenic over time as a result of the material that was brought into the subduction system/mantle wedge. The $T_{\mathrm{Zrc}}$ and $T_{\text {Apt }}$ estimates may also be supportive of the change in the subduction and melting geodynamics as the Albian rocks (i.e., Shiraishino granodiorite) have the higher mineral saturation temperatures, whereas older and younger rocks appear to have lower mineral saturation temperatures (Figure 9D). The higher temperatures for the granodiorites at Albian may imply the heat input into the magma source was higher during this time.

The magma source of the Shiraishino granodiorites was proposed to be subducted oceanic crust that melted due to asthenospheric upwelling and hot corner flow caused by slab rollback (Kamei, 2004; Kiminami and Imaoka, 2013; Imaoka et al., 2014; Kim et al., 2016). The proposed petrogenetic model is broadly consistent with the classification of the granodiorites as being related to slab failure using the $\mathrm{Nb}+\mathrm{Y}-\mathrm{Nb} / \mathrm{Y}$ 


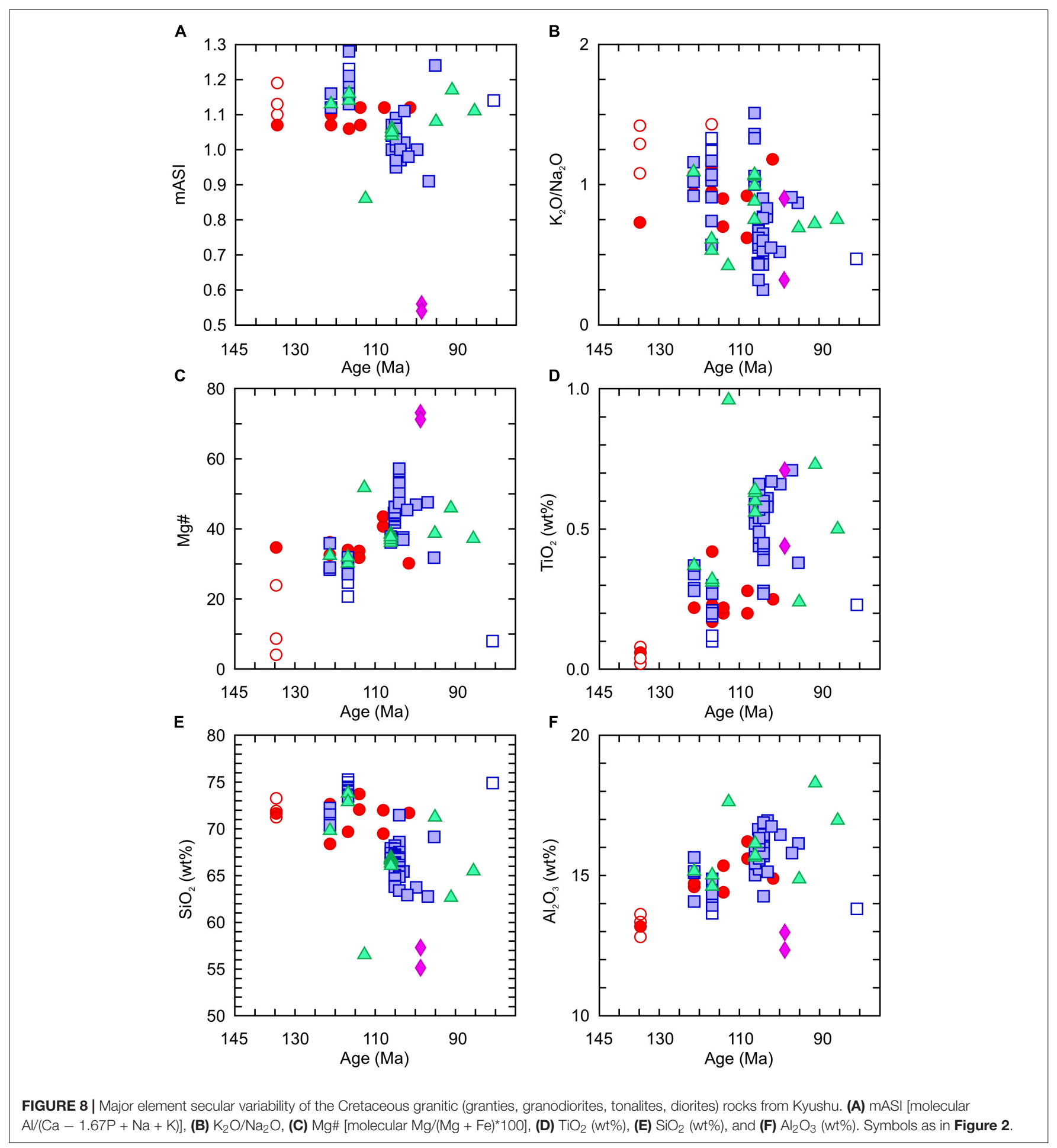

discrimination diagram (Figure 11), which implies that they were derived from partial melting of the upper layers of oceanic crust (Whalen and Hildebrand, 2019). In contrast, the other granitic rocks are thought to be derived by partial melting of mafic lower continental crust (Kamei, 2004), tonalitic middle crust (Kamei, 2002), and young and hot subducted oceanic crust (Kamei et al., 2004). However, the other granitic rocks are also classified as slab failure-related (Figure 11), suggesting they were derived from the same source as the Shiraishino granodiorites. The model proposed for the genesis of the Shiraishino granodiorites, as well as the other granitic rocks, can be tested as there are constraints on the type of source material that is representative the upper part of subducted oceanic crust in the region. For example, the proximal Nishisonogi chlorite-actinolite schist is interpreted to 

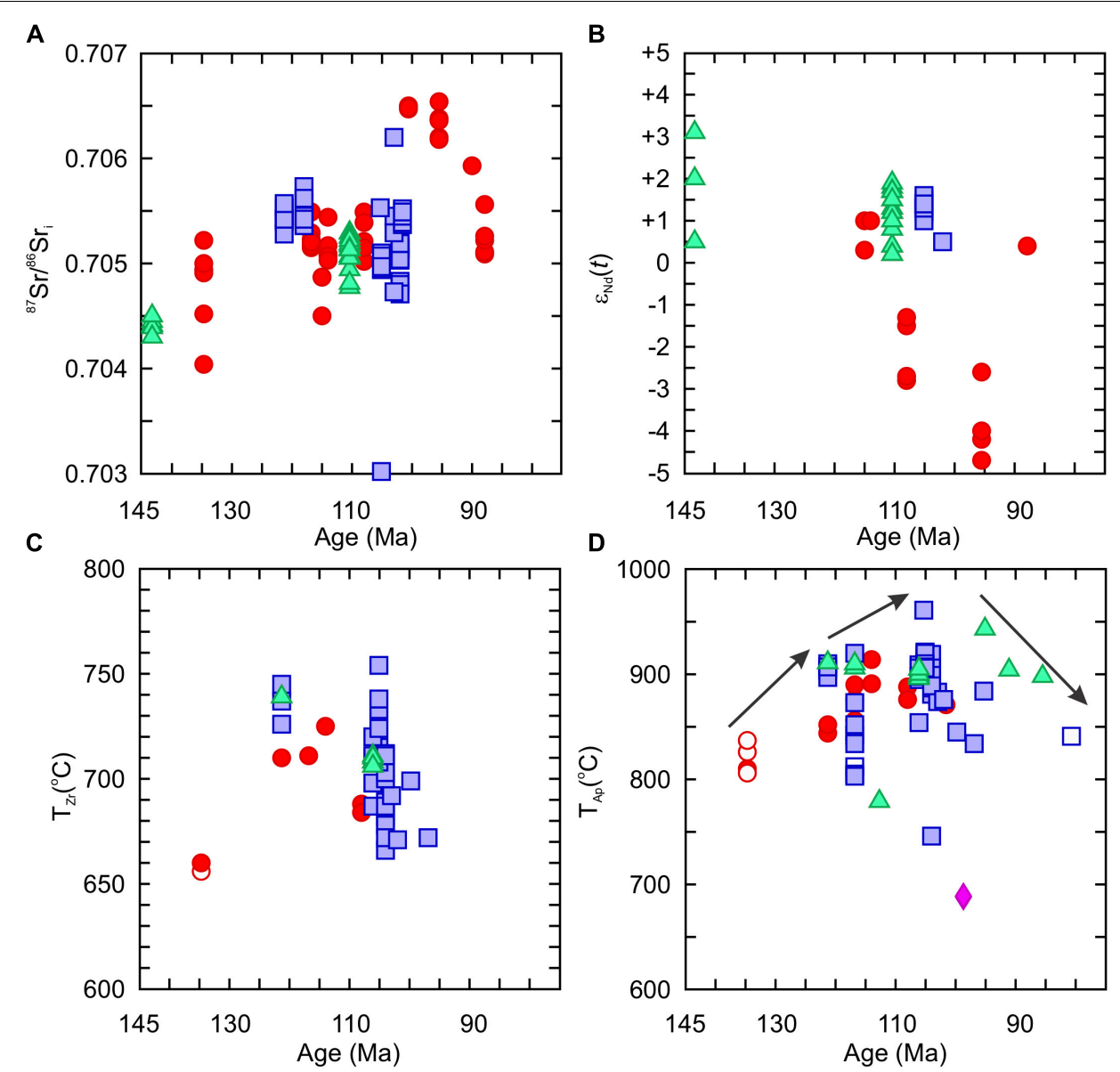

FIGURE 9 | Secular variation of (A) ${ }^{87} \mathrm{Sr}^{86} \mathrm{Sr}_{\mathrm{i}}$, (B) $\varepsilon_{\mathrm{Nd}}(t)$, (C) zircon saturation temperature $\left(T_{\mathrm{Zrc}}{ }^{\circ} \mathrm{C}\right)$, and (D) apatite saturation temperature $\left(T_{\mathrm{Apt}}{ }^{\circ} \mathrm{C}\right)$ in the Cretaceous granitic (granties, granodiorites, tonalites, diorites) rocks from Kyushu. Symbols as in Figure 2.

be a mélange sequence that was derived from the upper part of subducted oceanic crust and melting of these rock types are known to produce silicic melts (Marschall and Schumacher, 2012; Hao et al., 2016). In the following section, we present thermodynamic modeling in order to determine if granitic melts similar to the Albian rocks can be derived by partial melting of the Nishisonogi chlorite-actinolite schist.

\section{Thermodynamic Modeling of the Albian Granitic Rocks}

For this study, the origins of the Albian granitic rocks of Kyushu are evaluated as they appear to be derived from the same source (Figures 9A,B, 11) as discussed above. Namely, the Tsutsugatake granite (Kamei et al., 2009), the Shiraishino granodiorites (Kamei, 2004), the Manzaka tonalite (Kamei, 2002), the Kunisaki and Kita-Taku high-Mg diorites (Kamei et al., 2004), and the Kanmon andesites (Imaoka et al., 1993) (Figure 1). The reported ages in previous studies are $117 \pm 13 \mathrm{Ma}$ for the Tsutsugatake granite (Osanai et al., 1993), 121-100 Ma for the Shiraishino granodiorite (Nakajima et al., 1995; Kamei et al., 1997, 2000), $113 \pm 5$ Ma for the Manzaka tonalite (Sakashima et al., 2003), $99 \pm 5 \mathrm{Ma}$ for the Kunisaki high-Mg diorite (Kamei et al., 2004), and 105102 Ma for the Kanmon andesite (Imaoka et al., 1993; Matsuura, 1998). The age of the Kita-Taku high-Mg diorite, which occurs as a xenolith in the Kita-Taku gabbros (Oshima, 1961), is inferred to be c. $116 \mathrm{Ma}$, based on the geological relations of its host rocks with the surrounding granitic and metamorphic rocks (Owada et al., 1999; Kamei et al., 2004).

Equilibrium partial melting models were calculated using the Nishisonogi chlorite-actinolite schist as a proxy for mélange rocks in the region. Our goal is to determine if it is possible to derive some or all of the Albian granitic rocks from the Nishisonogo schist including: the Tsutsugatake granite, the Shiraishino granodiorites, the Manzaka tonalite, the Kunisaki and Kita-Taku high-Mg diorites, and the Kanmon andesites. We selected a starting composition that is typical of the Nishisonogi chlorite-actinolite schist (NK25; Mori et al., 2014; Table 1).

The thermodynamic modeling of granitic rocks can be modeled using the program Rhyolite-MELTS (Gualda et al., 2012). Rhyolite-MELTS as it is calibrated to the $\mathrm{SiO}_{2}-\mathrm{TiO}_{2}-\mathrm{Al}_{2} \mathrm{O}_{3}-$ $\mathrm{Fe}_{2} \mathrm{O}_{3}-\mathrm{Cr}_{2} \mathrm{O}_{3}-\mathrm{FeO}-\mathrm{MnO}-\mathrm{MgO}-\mathrm{CaO}-\mathrm{Na}_{2} \mathrm{O}-\mathrm{K}_{2} \mathrm{O}-\mathrm{P}_{2} \mathrm{O}_{5}-\mathrm{H}_{2} \mathrm{O}$ bulk composition system. The software is optimized for silicic systems and enables the user to adjust modeling parameters, such 


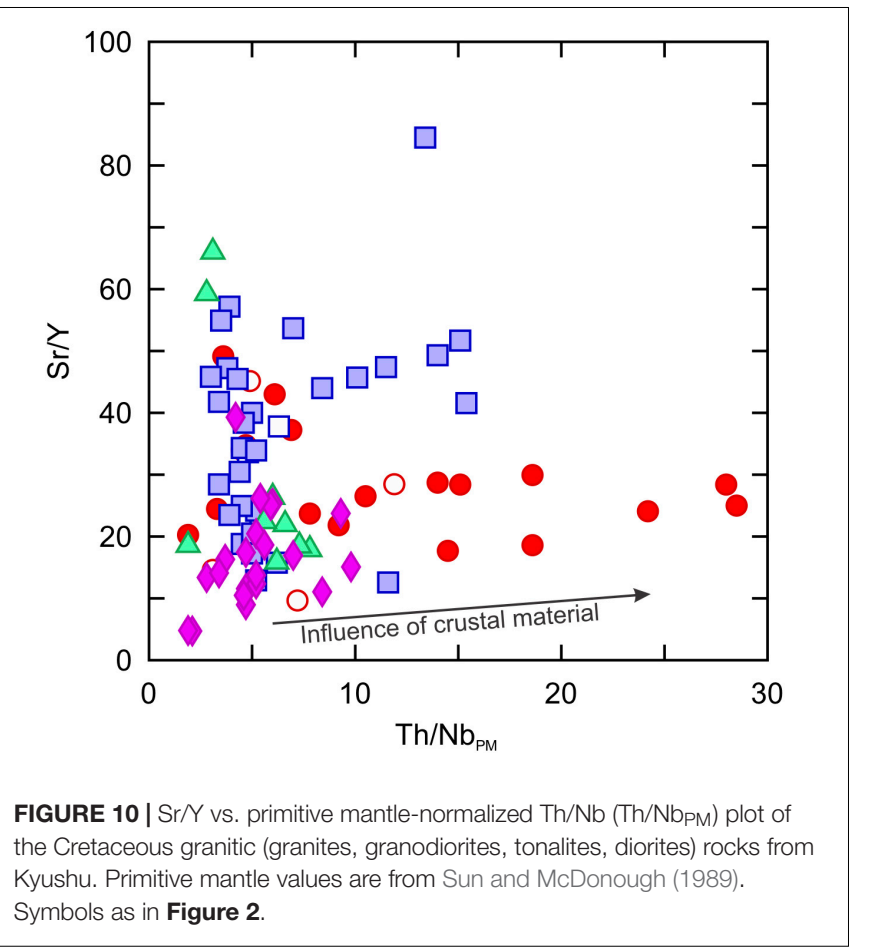

as pressure (bars), relative oxidation state $\left(f \mathrm{O}_{2}\right)$, and water (wt.\%) content of the system being modeled, in order to constrain the possible conditions and processes (i.e., fractional crystallization or partial melting). The crust of Kyushu is comprised of the Paleozoic-Mesozoic high- $P$ metamorphic rocks and Jurassic accretionary rocks, and its thickness is estimated to be $\sim 26 \mathrm{~km}$ (Arai et al., 2009). However, it is likely that the crust was thinner during the Cretaceous as it would not include the additional material added since the Cenozoic. Consequently, the initial pressure used for the modeling is $0.5 \mathrm{GPa}$ (i.e., $5 \mathrm{kbar}, \sim 20 \mathrm{~km}$ thickness) which is based on the likely depth of melting for the rocks. The relative oxidation state of the parental rock assemblage is not constrained and therefore we ran models using oxidation conditions that range from relatively reducing to relatively oxidizing (i.e., FMQ $-1, \mathrm{FMQ}+1$, and FMQ +3 ) with water contents of $0.5 \mathrm{wt} \%$.

The results are shown in Figure 12 at $10^{\circ} \mathrm{C}$ intervals, with models represented by different colored dots (i.e., white dots $=\mathrm{FMQ}-1$; black dots $=\mathrm{FMQ}+1$; gray dots $=\mathrm{FMQ}+3)$. The thermal window of the models for this study extends from 1300 to $700^{\circ} \mathrm{C}$ and represents $\sim 60$ to $\sim 0.3 \%$ melting of the source. The results indicate that the source composition, under the melting conditions outlined in Table 1, can reasonably produce the compositions of the Shiraishino granodiorite, the
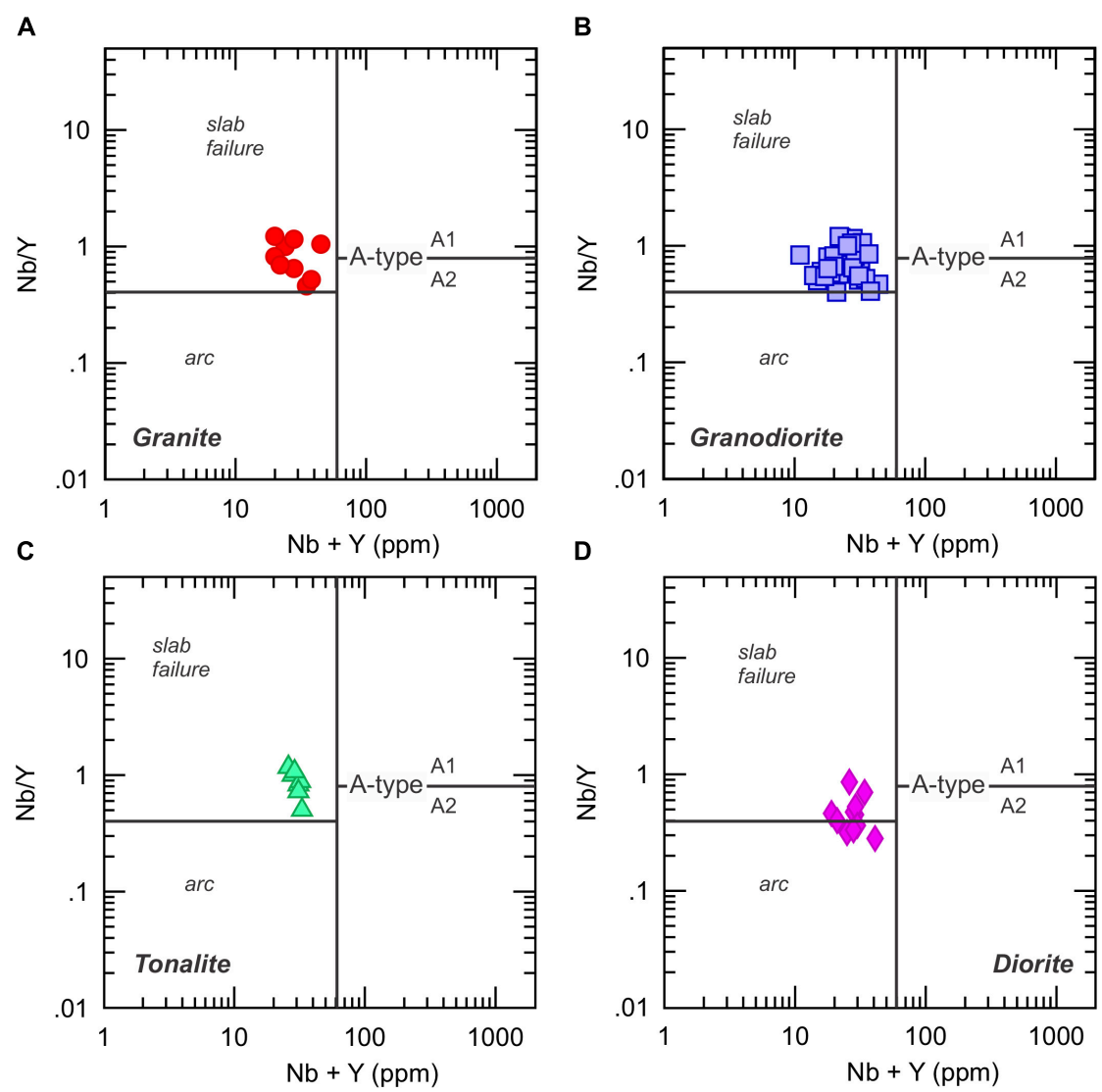

FIGURE 11 | Nb + Y (ppm) vs. Nb/Y discrimination plots used to separate arc, slab failure, and A-type (A1, A2) compositions of the Cretaceous (A) granites, (B) granodiorites, (C) tonalites, and (D) diorites from Kyushu (Whalen and Hildebrand, 2019). Symbols as in Figure 2. 
TABLE 1 | Starting compositions used for equilibrium partial melting models and compositions for Albian granitic rocks from Kyushu.

\begin{tabular}{|c|c|c|c|c|c|c|c|c|c|c|}
\hline \multirow{5}{*}{$\begin{array}{l}\text { Name } \\
\text { Sample } \\
\text { Lithology }\end{array}$} & \multicolumn{4}{|c|}{ Starting composition } & \multicolumn{6}{|c|}{ Albian granitic rocks from Kyushu } \\
\hline & $\begin{array}{c}\text { Nishisonogi } \\
\text { NK25 }\end{array}$ & Model 1 & Model 2 & Model 3 & $\begin{array}{c}\text { Tsutsugatake } \\
05031803\end{array}$ & $\begin{array}{c}\text { Shiraishino } \\
\text { Average }(n=12)\end{array}$ & $\begin{array}{c}\text { Manzaka } \\
\text { Average }(n=7)\end{array}$ & $\begin{array}{c}\text { Kunisaki } \\
98970505\end{array}$ & $\begin{array}{l}\text { Kita-Taku } \\
93100506\end{array}$ & $\begin{array}{c}\text { Kanmon } \\
\text { CH905 }\end{array}$ \\
\hline & Chlorite- & & & & & & & & & \\
\hline & actinolite & & & & & & & High-Mg & High-Mg & \\
\hline & schist & & & & Granite & Granodiorite & Tonalite & diorite & diorite & Andesite \\
\hline $\mathrm{SiO}_{2}(\mathrm{wt} . \%)$ & 51.98 & 54.25 & 54.25 & 54.25 & 74.69 & 66.21 & 56.53 & 55.14 & 52.93 & 57.62 \\
\hline $\mathrm{TiO}_{2}$ & 0.33 & 0.34 & 0.34 & 0.34 & 0.17 & 0.54 & 0.96 & 0.71 & 0.63 & 0.65 \\
\hline $\mathrm{Al}_{2} \mathrm{O}_{3}$ & 5.33 & 5.56 & 5.56 & 5.56 & 14.02 & 15.81 & 17.62 & 12.97 & 6.67 & 17.17 \\
\hline $\mathrm{Fe}_{2} \mathrm{O}_{3} \mathrm{t}$ & 8.83 & 9.22 & 9.22 & 9.22 & 1.26 & 3.61 & 6.58 & 7.75 & 9.84 & 6.80 \\
\hline $\mathrm{MnO}$ & 0.16 & 0.17 & 0.17 & 0.17 & 0.04 & 0.08 & 0.13 & 0.16 & 0.22 & 0.05 \\
\hline $\mathrm{MgO}$ & 19.00 & 19.83 & 19.83 & 19.83 & 0.30 & 1.64 & 3.95 & 9.65 & 13.23 & 3.07 \\
\hline $\mathrm{CaO}$ & 8.58 & 8.95 & 8.95 & 8.95 & 1.18 & 3.88 & 7.41 & 10.81 & 13.43 & 5.02 \\
\hline $\mathrm{Na}_{2} \mathrm{O}$ & 0.93 & 0.97 & 0.97 & 0.97 & 3.43 & 3.88 & 3.46 & 2.21 & 1.09 & 5.26 \\
\hline $\mathrm{K}_{2} \mathrm{O}$ & 0.09 & 0.09 & 0.09 & 0.09 & 3.79 & 2.23 & 1.44 & 0.71 & 0.36 & 2.95 \\
\hline $\mathrm{P}_{2} \mathrm{O}_{5}$ & 0.11 & 0.11 & 0.11 & 0.11 & 0.03 & 0.16 & 0.14 & 0.07 & 0.11 & 0.13 \\
\hline $\mathrm{H}_{2} \mathrm{O}$ & & 0.5 & 0.5 & 0.5 & & & & & & \\
\hline Pressure & & $0.5 \mathrm{GPa}$ & $0.5 \mathrm{GPa}$ & $0.5 \mathrm{GPa}$ & & & & & & \\
\hline $\mathrm{fO}_{2}$ & & $\mathrm{FMQ}-1$ & $\mathrm{FMQ}+1$ & $\mathrm{FMQ}+3$ & & & & & & \\
\hline
\end{tabular}

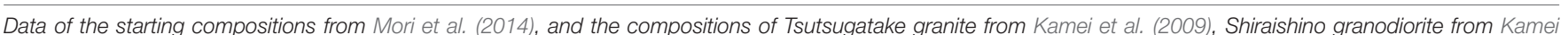

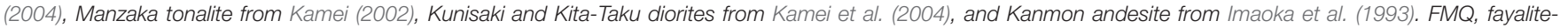
magnetite-quartz buffer.

Manzaka tonalite, the Kunisaki and Kita-Taku high-Mg diorites, and the Kanmon andesites for the exception of $\mathrm{K}_{2} \mathrm{O}$. Moreover, the modeling results could not replicate the highly silicic Tsutsugatake granites suggesting an additional process (e.g., fractional crystallization, assimilation-fractional crystallization) or possibly source is required to generate highly evolved rocks.

The thermodynamic modeling demonstrates that equilibrium partial melting of chlorite-actinolite schists can produce the Early Cretaceous granitic rocks, except for the highly silicic Tsutsugatake granites (Figure 12). The compositions of the Manzaka tonalite ( $\sim 20$ to $\sim 25 \%$ melting), the Kunisaki high$\mathrm{Mg}$ diorite ( $\sim 30$ to $\sim 37 \%$ melting), and the Kanmon andesite ( $\sim 20$ to $\sim 25 \%$ melting) rocks are best replicated with a relatively reducing oxidation state (i.e., FMQ -1 ), whereas the rocks from Shiraishino granodiorite (FMQ $+1=\sim 18 \%$ melting; FMQ $+3=\sim 9$ to $\sim 13 \%$ melting) favor oxidizing conditions $(\mathrm{FMQ}+1$ or +3$)$, which is consistent with their relatively high $\mathrm{Eu} / \mathrm{Eu}^{*}(\sim 1.1)$. The Kita-Taku high-Mg diorite probably requires more melting (i.e., $65-70 \%$ ), but the relative oxidation state does not appear exert a strong influence on the composition.

Although the models show that there is good agreement between the liquid evolution curves and the bulk composition of the granitic rocks, the $\mathrm{K}_{2} \mathrm{O}$ content in each model is consistently too low (Figure 12). The explanations for the discrepancy between the model curves and the $\mathrm{K}_{2} \mathrm{O}$ concentration are either related to the highly mobile nature of $\mathrm{K}^{+}$during metamorphism to hydrothermal alteration or to the fact that the Nishisonogi chlorite-actinolite schist is not a perfect analog of the mélange rocks that melted during the Albian (Wood et al., 1976; Kogiso et al., 1997; Zheng et al., 2011).

\section{Tectonomagmatic Evolution of the Early Cretaceous Granitic Rocks}

It is thought that slab rollback during the Early Cretaceous, following a shallowing of the subduction angle and subsequent flat-slab subduction during the Late Jurassic, changed the geotectonic setting of SW Japan from subduction-accretion to continental arc (Kiminami and Imaoka, 2013; Kim et al., 2016). As a result of the slab rollback, a slab gap could be created and filled with an upwelling asthenosphere, creating a 'hot corner' within the mantle wedge. The change in subduction geodynamics is expected to be reflected in the secular compositional and temperature variations of the granitic rocks.

The initiation of asthenospheric upwelling and hot corner flow caused by slab rollback likely began during the Berriasian as the tonalites have the most radiogenic $\mathrm{Sr}$ and $\mathrm{Nd}$ isotopic values $\left[{ }^{87} \mathrm{Sr} /{ }^{86} \mathrm{Sr}_{\mathrm{i}}=0.70430\right.$ to $0.70450 ; \varepsilon_{\mathrm{Nd}}(t)=+0.5$ to +3.1 ; Figures $9 \mathbf{A}, \mathbf{B}]$. The magmatic source is likely juvenile or at least the rocks were derived from a radiogenic source under the lower continental crust or from subducted oceanic crust. Once slab rollback began, it is possible that the dip of the subducted slab increased and more sediments were transported along the subducted plate interface into the mantle wedge, likely causing a magma source to become more isotopically enriched. This is consistent with the increase of ${ }^{87} \mathrm{Sr} /{ }^{86} \mathrm{Sr}_{i}$ ratios and decrease of $\varepsilon_{\mathrm{Nd}}(t)$ values of granitic rocks during Beriasian to Albian (Figures 9A,B). The maximum temperatures experienced by the granitic rocks $\left(T_{\mathrm{Apt}}\right)$ also increased over time, indicating that there may be higher heat flow or melting conditions due to the input of upwelling asthenosphere into the mantle wedge and development of hot corner flow (Figures 9C,D). 

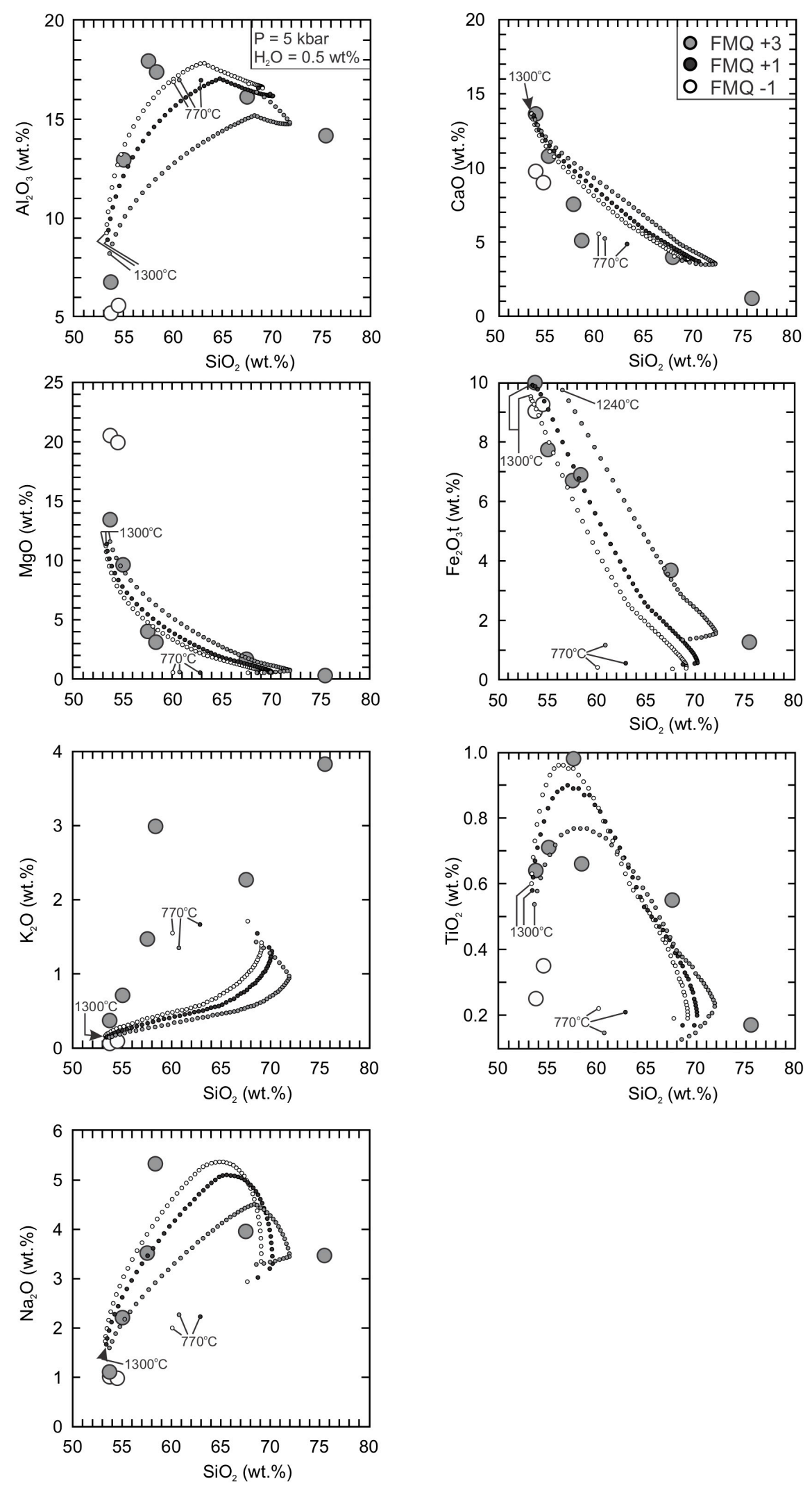

FIGURE 12 | (A-G) Results of equilibrium partial melting showing the liquid evolution paths of the Nishisonogi chlorite-actinolite schist with models represented by different colored dots (i.e., white dots $=F M Q-1$; black dots $=F M Q+1$; gray dots $=F M Q+3$ ). Each dot represents a $10^{\circ} \mathrm{C}$ interval of melting . 
During the Albian and the Valanginian to Coniacian, the granitic rocks have similar ${ }^{87} \mathrm{Sr} /{ }^{86} \mathrm{Sr}_{\mathrm{i}}$ ratios and $\varepsilon_{\mathrm{Nd}}(t)$ values independent of rock type (Figures 9A,B) as described above, although some granites at $\sim 95 \mathrm{Ma}$ have higher ${ }^{87} \mathrm{Sr} /{ }^{86} \mathrm{Sr}_{\mathrm{i}}$ ratios and lower $\varepsilon_{\mathrm{Nd}}(t)$ values, which might be explained by crustal contamination during emplacement or they were derived by partial melting of the crust as discussed above. The peak of maximum temperatures $\left(T_{\mathrm{Apt}}\right)$ occurred during the Albian, but the rate of temperature changes decreased in this period (Figures 9C,D). These lines of evidence suggest the inputs of heat and sediments into the mantle wedge may be close to 'steady state, probably due to the subducted slab reaching a stable angle. The stable subduction angle was likely the key development that enabled the generation of melts from a relatively uniform source for the granodiorites, tonalites, and possibly the least evolved granitic rocks.

The magmatic source during the Albian could be similar to mélange rocks, such as chlorite-actinolite schists, which are intensely mixed and metasomatised rocks on the subducting plate interface, and contain the chemical components characteristic for the generation of arc magma at subduction zone settings (Marschall and Schumacher, 2012). The mélange rocks may be transported as a diapir or plume into the hot corner of the mantle wedge where the dehydration and partial melting of the mélange rocks could generate a range of fluid and melt compositions (Marschall and Schumacher, 2012). Equilibrium partial melting modeling of chlorite-actinolite schists suggests that it is possible that they could produce magma similar to the Albian rocks at moderate depth and variable redox conditions, indicating that this may be a viable process that produced some of the Kyushu granitic rocks (Figure 12).

\section{CONCLUSION}

The Early Cretaceous granitic rocks from Kyushu, SW Japan, formed in a volcanic-arc setting. Important geodynamic changes in the heat supply and magmatic sources occurred during the Berriasian to Albian. Upwelling of the asthenosphere and hot corner flow into the mantle wedge caused by slab rollback,

\section{REFERENCES}

Adachi, T., Osanai, Y., Nakano, N., and Owada, M. (2012). LA-ICP-MS U-Pb zircon and FE-EPMA U-Th-Pb monazite dating of pelitic granulites from the Mt. Ukidake area, Sefuri Mountains, northern Kyushu. J. Geol. Soc. Jpn. 118, 39-52. doi: 10.5575/geosoc.2011.0022

Arai, R., Iwasaki, T., Sato, H., Abe, S., and Hirata, N. (2009). Collision and subduction structure of the Izu-Bonin arc, central Japan, revealed by refraction/wide-angle reflection analysis. Tectonophysics 475, 438-453. doi: 10 . 1016/j.tecto.2009.05.023

Arculus, R. J. (2003). Use and abuse of the terms calcalkaline and calcalkalic. J. Petrol. 44, 929-935. doi: 10.1093/petrology/44.5.929

Boehnke, P., Watson, E. B., Trail, T., Harrison, T. M., and Schmitt, A. K. (2013). Zircon saturation re-visited. Chem. Geol. 351, 324-334. doi: 10.1016/j.chemgeo. 2013.05.028

Buddington, A. F., and Lindsley, D. H. (1964). Iron-titanium oxide minerals and synthetic equivalents. J. Petrol. 5, 310-357. doi: 10.1093/petrology/5.2.310 following a shallowing of the subduction angle and subsequent flat-slab subduction during the Late Jurassic, likely supplied the heat for partial melting of upper plate mélange rocks or the initiation of diapirs that formed on the subducted plate-mantle interface. This process was likely responsible for dehydration and partial melting of the subducted slab. The partial melting of the mélange rocks such as chlorite-actinolite schists at high to moderate pressure can yield melts that are similar to the bulk compositions observed in the Albian granitic rocks including the adakitic rocks of the Shiraishino granodiorites. Melting of the same source could also explain the relative $\mathrm{Sr}-\mathrm{Nd}$ isotopic homogeneity of the Albian rocks.

\section{DATA AVAILABILITY STATEMENT}

All datasets generated for this study are included in the article/Supplementary Material.

\section{AUTHOR CONTRIBUTIONS}

KS contributed to conception and design of the study and wrote the manuscript. M-WY contributed to interpretation of data for the work. Both authors contributed to manuscript revision, read and approved the submitted version.

\section{ACKNOWLEDGMENTS}

We thank Dr. Kwan-Nang Pan for handling of the manuscript and Profs. D. R. Lentz and J. V. Owen for their constructive comments. KS is grateful to Robert Hsieh for his assistance and Prof. J. G. Shellnutt for his guidance and support.

\section{SUPPLEMENTARY MATERIAL}

The Supplementary Material for this article can be found online at: https://www.frontiersin.org/articles/10.3389/feart. 2020.00095/full\#supplementary-material

Chen, J. F., and Jahn, B. M. (1998). Crustal evolution of southeastern China: Nd and Sr isotopic evidence. Tectonophysics 284, 101-133. doi: 10.1016/s00401951(97)00186-8

Christiansen, E. H., and Keith, J. D. (1996). "Trace element systematics in silicic magmas: a metallogenic perspective," in Trace Element Geochemistry of Volcanic Rocks: Applications for Massive Sulphide Exploration, ed. D. A. Wyman (Canada: Geology Association), 115-151.

Dong, S., Zhang, Y., Li, H., Shi, W., Xue, H., Li, J., et al. (2018). The Yanshan orogeny and late Mesozoic multi-plate convergence in East AsiaCommemorating 90th years of the "Yanshan Orogeny". Sci. China Earth Sci. $61,1-22$.

Ernst, W. G., Tsujimori, T., Zhang, R., and Liou, J. G. (2007). Permo-Triassic collision, subduction-zone metamorphism, and tectonic exhumation along the East Asian continental margin. Ann. Rev. Earth Planet. Sci. 35, 73-110. doi: 10.1146/annurev.earth.35.031306.140146

Faure, M., Fabbri, O., and Monie, P. (1988). The Miocene bending of southwest Japan: new 39Ar/40Ar and microtectonic constraints from the Nagasaki schist 
(western Kyushu), an extension of the Sanbagawa high-pressure belt. Earth Planet. Sci. Lett. 91, 13-31.

Forster, H. J., Tischendorf, G., and Trumbull, R. B. (1997). An evaluation of the Rb vs. $(\mathrm{Y}+\mathrm{Nb})$ discrimination diagram to infer tectonic setting of silicic igneous rocks. Lithos 40, 261-293. doi: 10.1016/s0024-4937(97)00032-7

Frost, B. R., Barnes, C. G., Collins, W. J., Arculus, R. J., Ellis, D. J., and Frost, C. D. (2001). A geochemical classification for granitic rocks. J. Petrol. 42, 2033-2048. doi: 10.1093/petrology/42.11.2033

Fujii, M., Hayasaka, Y., and Horie, K. (2008). Metamorphism and timing of the nappe movement in the Asaji metamorphic area, eastern Kyusu. J. Geol. Soc. Japan 114, 127-140. doi: 10.5575/geosoc.114.127

Fukuyama, M., Ogasawara, M., Dunkley, D. J., Wang, K. L., Lee, D. C., Hokada, T., et al. (2014). The formation of rodingite in the Nagasaki metamorphic rocks at Nomo Peninsula, Kyushu, Japan - Zircon $\mathrm{U}-\mathrm{Pb}$ and Hf isotopes and trace element evidence. Island Arc 23, 281-298. doi: 10.1111/iar.12086

Gualda, G. A. R., Ghiorso, M. S., Lemons, R. V., and Carley, T. L. (2012). Rhyolite-MELTS: a modified calibration of MELTS optimized for silica-rich, fluid-bearing magmatic systems. J. Petrol. 53, 875-890. doi: 10.1093/petrology/ egr080

Hamamoto, T., Osanai, Y., and Kagami, H. (1999). Sm-Nd, Rb-Sr and K-Ar geochronology of the Higo metamorphic terrane, west-central Kyushu, Japan. island Arc 8, 323-334. doi: 10.1046/j.1440-1738.1999.00240.x

Hao, L. L., Wang, Q., Wyman, D. A., Qu, Q., Dan, W., Jiang, Z. Q., et al. (2016). Andesitic crustal growth via mélange partial melting: evidence from early cretaceous arc dioritic/andesitic rocks in southern Qiangtang, central Tibet. Geochem. Geophys. Geosyst. 17, 1641-1659. doi: 10.1002/2016gc006248

Harrison, T. M., and Watson, E. B. (1984). The behavior of apatite during crustal anatexis: equilibrium and kinetic considerations. Geochim. Cosmochim. Acta. 48, 1467-1477. doi: 10.1016/0016-7037(84)90403-4

Hattori, H., and Shibata, K. (1982). Radiometric dating of Pre-Neogene granitic and metamorphic rocks in northwest Kyushu, Japan - with emphasis on geotectonics of the Nishisonogi zone. Bull. Geol. Surv. Japan 33, 57-84.

Hou, M. L., Jiang, Y. H., Jiang, S. Y., Ling, H. F., and Zhao, K. D. (2007). Contrasting origins of late Mesozoic adakitic granitoids from the northwestern Jiaodong Peninsula, east China: implications for crustal thickening to delamination. Geol. Mag. 144, 619-631. doi: 10.1017/s0016756807003494

Imaoka, T., Nakajima, T., and Itaya, T. (1993). K - Ar ages of hornblendes in andesite and dacite from the Cretaceous Kanmon Group, southwest Japan. J. Min. Petrol. Econ. Geol. 88, 265-271. doi: 10.2465/ganko.88.265

Imaoka, T., Nakashima, K., Kamei, A., Itaya, T., Ohira, T., Nagashima, M., et al. (2014). Episodic magmatism at $105 \mathrm{Ma}$ in the Kinki district, SW Japan: petrogenesis of Nb-rich lamprophyres and adakites, and geodynamic implications. Lithos 184-187, 105-131. doi: 10.1016/j.lithos.2013.10.014

Ishiwatari, A., and Tsujimori, T. (2003). Paleozoic ophiolites and blueschists in Japan and Russian Primorye in the tectonic framework of East Asia: a synthesis. Island Arc 12, 190-206. doi: 10.1046/j.1440-1738.2003.00390.x

Isozaki, Y., Aoki, K., Nakama, T., and Yanai, S. (2010). New insight into a subduction-related orogen: a reappraisal of the geotectonic framework and evolution of the Japanese Islands. Gondwana Res. 18, 82-105. doi: 10.1016/j. gr.2010.02.015

Kamei, A. (2002). Petrogenesisof cretaceous peraluminous granite suites with low initial Sr isotopic ratios, Kyushu Island, southwest Japan arc. Gondwana Res. 5, 813-822. doi: 10.1016/s1342-937x(05)70915-1

Kamei, A. (2004). An adakitic pluton on Kyushu Island, southwest Japan arc. J. Asian Earth Sci. 24, 43-58. doi: 10.1016/j.jseaes.2003.07.001

Kamei, A., Miyake, Y., Owada, M., and Kimura, J. (2009). A pseudo adakite derived from partial melting of tonalitic to granodioritic crust, Kyushu, southwest Japan arc. Lithos 112, 615-625. doi: 10.1016/j.lithos.2009.05.024

Kamei, A., Owada, M., Hamamoto, T., Osanai, Y., Yuhara, M., and Kagami, H. (2000). Isotopic equilibration ages for the Miyanohara tonalite from the Higo metamorphic belt in central Kyushu, Southwest Japan: implications for the tectonic setting during the Triassic. Island Arc 9, 97-112. doi: 10.1046/j.14401738.2000.00264.x

Kamei, A., Owada, M., Nagao, T., and Shiraki, K. (2004). High-Mg diorites derived from sanukitic HMA magmas, Kyushu Island, southwest Japan arc: evidence from clinopyroxene and whole rock compositions. Lithos 75, 359-371. doi: 10.1016/j.lithos.2004.03.006

Kamei, A., Owada, M., Osanai, Y., Hamamoto, T., and Kagami, H. (1997). Solidification and cooling ages for the Higo plutonic rocks in the Higo metamorphic terrane, central Kyushu. J. Min. Petrol. Econ. Geol. 92, 316-326. doi: 10.2465/ganko.92.316

Kim, S. W., Kwon, S., Park, S. I., Lee, C., Cho, D. L., Lee, H. J., et al. (2016). SHRIMP $\mathrm{U}-\mathrm{Pb}$ dating and geochemistry of the Cretaceous plutonic rocks in the Korean Peninsula: a new tectonic model of the Cretaceous Korean Peninsula. Lithos 262, 88-106. doi: 10.1016/j.lithos.2016.06.027

Kiminami, K., and Imaoka, T. (2013). Spatiotemporal variations of JurassicCretaceous magmatism in eastern Asia (Tan-Lu Fault to SW Japan): evidence for flat-slab subduction and slab rollback. Terra Nova 25, 414-422. doi: 10. $1111 /$ ter. 12051

Kogiso, T., Tatsumi, Y., and Nakano, S. (1997). Trace element transport during dehydration processes in the subducted oceanic crust: 1. Experiments and implications for the origin of ocean island basalts. Earth Planet. Sci. Lett. 148, 193-205. doi: 10.1016/s0012-821x(97)00018-6

Kouchi, Y., Orihashi, Y., Obara, H., Miyata, K., Shimojo, M., Otoh, S., et al. (2011). Discovery of Shimanto high-P/T metamorphic rocks from the western margin of Kyushu, Japan. J. Geogr. 120, 30-39. doi: 10.5026/jgeography. 120.30

Lan, T. G., Fan, H. R., Santosh, M., Hu, F. F., Yang, K. F., Yang, Y. H., et al. (2011). Geochemistry and $\mathrm{Sr}-\mathrm{Nd}-\mathrm{Pb}-\mathrm{Hf}$ isotopes of the Mesozoic Dadian alkaline intrusive complex in the Sulu orogenic belt, eastern China: implications for crust-mantle interaction. Chem. Geol. 285, 97-114. doi: 10.1016/j.chemgeo. 2011.03 .013

Li, Z. X., and Li, X. H. (2007). Formation of the 1300-km wide intracontinental orogen and postorogenic magmatic province in Mesozoic South China: a flat-slab subduction model. Geology 35, 179-182.

Marschall, H. R., and Schumacher, J. C. (2012). Arc magmas sourced from meilange diapirs in subduction zones. Nat. Geosci. 5, 862-867. doi: 10.1038/ngeol634

Maruyama, S., Isozaki, Y., Kimura, G., and Terabayashi, M. (1997). Paleogeographic maps of the Japanese Islands: plate tectonic synthesis from $750 \mathrm{Ma}$ to the present. Island Arc 6, 121-142. doi: 10.1111/j.1440-1738. 1997.tb00043.x

Matsuura, H. (1998). K-Ar ages of the Early Cretaceous Shimonoseki Subgroup and Kawara granodiorites, southwest Japan. J. Min. Petrol. Econ. Geol. 93, 307-312. doi: 10.2465/ganko.93.307

Miller, C. F., McDowell, S. M., and Mapes, R. W. (2003). Hot and cold granites? Implications of zircon saturation temperatures and preservation of inheritance. Geology 31, 529-532.

Miyazaki, K., Ikeda, T., Matsuura, H., Danhara, T., Iwano, H., and Hirata, T. (2018). Ascent of migmatites of a high-temperature metamorphic complex due to buoyancy beneath a volcanic arc: a mid-Cretaceous example from the eastern margin of Eurasia. Int. Geol. Rev. 61, 649-674. doi: 10.1080/00206814.2018. 1443403

Miyazaki, K., Ozaki, M., Saito, M., and Toshimitsu, S. (2016). "The kyushuryukyu arc," in The Geology of Japan, eds, T. Moreno, S. Wallis, T. Kojima, and W. Gibbons (London: Geological Society of London), 139-174. doi: 10.1144/ goj.6

Miyazaki, K., Suga, K., Mori, Y., Iwano, H., Yagi, K., Shigeno, M., et al. (2019). Kinetics and duration of metamorphic mineral growth in a subduction complex: zircon and phengite in the Nagasaki metamorphic complex, western Kyushu, Japan. Contrib. Min. Petrol. 174, 1-19.

Miyoshi, M., Yuguchi, T., Shinmura, T., Mori, Y., Arakawa, Y., and Toyohara, F. (2011). Petrological characteristics and K-Ar age of borehole core samples of basement rocks from the northwestern caldera floor of Aso, central Kyushu. J. Geol. Soc. Japan 117, 585-590. doi: 10.5575/geosoc.117.585

Mori, Y., Nishiyama, T., and Yanagi, T. (2007). Chemical mass balance in a reaction zone between serpentinite and metapelites in the Nishisonogi metamorphic rocks, Kyushu, Japan: implications for devolatilization. Island Arc 16, 28-39. doi: 10.1111/j.1440-1738.2007.00556.x

Mori, Y., Orihashi, Y., Miyamoto, T., Shimada, K., Shigeno, M., and Nishiyama, T. (2011). Origin of zircon in jadeitite from the Nishisonogi metamorphic rocks, Kyushu, Japan. J. Metamorph. Geol. 29, 673-684. doi: 10.1111/j.1525-1314. 2011.00935.X

Mori, Y., Shigeno, M., and Nishiyama, T. (2014). Fluid-metapelite interaction in an ultramafic meilange: implications for mass transfer along the slab-mantle interface in subduction zones. Earth Planets Space 66, 1-8.

Nakajima, T., Nagakawa, K., Obata, M., and Uchiumi, S. (1995). Rb-Sr and K-Ar ages of the Higo metamorphic rocks and related granitic rocks, southwest Japan. J. Geol. Soc. Jpn. 101, 615-620. doi: 10.5575/geosoc.101.615 
Nguyen, T. T. B., Satir, M., Siebel, W., and Chen, F. (2004). Granitoids in the Dalat zone, southern Vietnam: age constraints on magmatism and regional geological implications. Int. J. Earth Sci. 93, 329-340.

Nishimura, Y. (1998). Geotectonic subdivision and areal extent of the Sangun belt, inner zone of southwest Japan. J. Metamorphic Geol. 16, 129-140. doi: 10.1111/j.1525-1314.1998.00059.x

Nishimura, Y., Hirota, Y., Shiosaki, D., Nakahara, N., and Itaya, T. (2004). The Nagasaki metamorphic rocks and their geotectonics in Mogi area, Nagasaki Prefecture, southwest Japan -Juxtaposition of the Suo belt with the Sanbagawa belt-. J. Geol. Soc. Jpn. 110, 372-383. doi: 10.5575/geosoc. 110.372

Nishiyama, T. (1978). Jadeitite from the Nishisonogi metamorphic region. J. Geol. Soc. Jpn. 84, 155-156.

Nishiyama, T. (1989). Petrological study of the Nagasaki metamorphic rocks in the Nishisonogi Peninsula -with special reference to the greenrock complex and the reaction-enhanced ductility-. Mem. Geol. Soc. Jpn. 33, 237-257.

Nishiyama, T. (1990). CO2-metasomatism of a metabasite block in a serpentine melange from the Nishisonogi metamorphic rocks, southwest Japan. Contrib. Min. Petrol. 104, 35-46. doi: 10.1007/bf00310644

Oh, C. W., and Kusky, T. (2007). The late permian to triassic hongseong-odesan collision belt in south Korea, and its tectonic correlation with China and Japan. Int. Geol. Rev. 49, 636-657. doi: 10.2747/0020-6814.49.7.636

Omori, S., and Isozaki, Y. (2011). Paleozoic Japan and the eastern extension of the collisional suture between the North and South China Cratons. J. Geography 120, 40-51. doi: 10.5026/jgeography.120.40

Osanai, Y., Hamamoto, T., Kagami, H., Suzuki, K., Owada, M., and Kamei, A. (1999). The Higo high-grade metamorphic rocks in Japan as a part of the collisional terrane between the Sino-Korean and Yangtze Cratons. Gondwana Res. 2, 599-601. doi: 10.1016/s1342-937x(05)70211-2

Osanai, Y., Masao, S., and Kagami, H. (1993). Rb - Sr whole rock isochron ages of granitic rocks from the central Kyushu, Japan. Mem. Geol. Soc. Jpn. 42, 135-150.

Osanai, Y., Owada, M., Kamei, A., Hamamoto, T., Kagami, H., Toyoshima, T., et al. (2006). The Higo metamorphic complex in Kyushu, Japan as the fragment of Permo-Triassic metamorphic complexes in East Asia. Gondwana Res. 9, 152-166. doi: 10.1016/j.gr.2005.06.008

Osborn, E. F. (1959). Role of oxygen partial pressure in the crystallization and differentiation of basaltic magma. Am. J. Sci. 257, 609-647. doi: 10.2475/ajs. 257.9.609

Oshima, T. (1961). The Kitataku gabbro-complex, Taku City, Saga prefecture. Fac. J. Saga Univ. 10, 87-100.

Owada, M., Kamei, A., Yamamoto, K., Osanai, Y., and Kagami, H. (1999). Spatialtemporal variations and origin of granitic rocks from central to northern part of Kyushu. Mem. Geol. Soc. Jpn. 53, 349-363.

Pearce, J. A., Harris, N. B., and Tindle, A. G. (1984). Trace element discrimination diagrams for the tectonic interpretation of granitic rocks. J. Petrol. 25, 956-983. doi: 10.1093/petrology/25.4.956

Plank, T., Kelley, K. A., Zimmer, M. M., Hauri, E. H., and Wallace, P. J. (2013). Why do mafic arc magmas contain $\sim 4 \mathrm{wt} \%$ on average? Earth Planet. Sci. Lett. 364, 168-179. doi: 10.1016/j.epsl.2012.11.044

Sakashima, T., Terada, K., Takeshita, T., and Sano, Y. (2003). Large-scale displacement along the Median Tectonic Line, Japan: evidence from SHRIMP zircon $\mathrm{U}-\mathrm{Pb}$ dating of granites and gneisses from the South Kitakami and paleoRyoke belts. J. Asian Earth Sci. 21, 1019-1039. doi: 10.1016/s1367-9120(02) 00108-6

Sasada, M. (1987). Pre-Tertiary basement rocks of Hohi area, central Kyushu, Japan. Bull. Geol. Surv. Jpn. 38, 385-422.

Shellnutt, J. G., Lan, C.-Y., Long, T. V., Usuki, T., Yang, H.-J., Mertzman, S. A., et al. (2013). Formation of Cretaceous Cordilleran and post-orogenic granites and their microgranular enclaves from the Dalat zone, southern Vietnam: tectonic implications for the evolution of southeast Asia. Lithos 182-183, 229-241. doi: 10.1016/j.lithos.2013.09.016

Shigeno, M., Mori, Y., and Nishiyama, T. (2005). Reaction microtextures in jadeitites from the Nishisonogi metamorphic rocks, Kyushu, Japan. J. Min. Petrol. Sci. 100, 237-246. doi: 10.2465/jmps.100.237
Shigeno, M., Mori, Y., Shimada, K., and Nishiyama, T. (2012a). Jadeitites with metasomatic zoning from the Nishisonogi metamorphic rocks, western Japan: fluid-tectonic block interaction during exhumation. Eur. J. Min. 24, 289-311. doi: 10.1127/0935-1221/2012/0024-2195

Shigeno, M., Mori, Y., Shimada, K., and Nishiyama, T. (2012b). Origin of omphacitites from the Nishisonogi metamorphic rocks, western Kyushu, Japan: comparison with jadeitites. Eur. J. Min. 24, 247-262. doi: 10.1127/0935-1221/ 2012/0024-2198

Suga, K., Yui, T. F., Miyazaki, K., Sakata, S., Hirata, T., and Fukuyama, M. (2017). A revisit to the Higo terrane, Kyushu, Japan: the eastern extension of the North China-South China collision zone. J. Asian Earth Sci. 143, 218-235. doi: 10.1016/j.jseaes.2017.04.006

Sun, S. S., and McDonough, W. F. (1989). "Chemical and isotopic systematics of oceanic basalts: implications for mantle composition and processes," in Magmatism in the Ocean Basins, eds A. D. Saunders, and M. J. Norry (London: Geol. Soc. London Spec. Publ.), 313-435.

Takagi, H., Ishii, T., Tobe, E., Soda, Y., Suzuki, K., Iwano, H., et al. (2007). Petrology and radiogenic age of accidental clasts of granitic mylonite from the Aso-4 pyroclastic flow deposit and their correlation to the Nioki Granite. J. Geol. Soc. Jpn. 113, 1-14. doi: 10.5575/geosoc.113.1

Takagi, H., Soda, Y., and Yoshimura, J. (2000). K - Ar ages of the granitic clasts from the Onogawa Group, eastern Kyushu. Mem. Geol. Soc. Jpn. 56, 213-220.

Tiepolo, M., Langone, A., Morishita, T., and Yuhara, M. (2012). On the recycling of amphibole-rich ultramafic intrusive rocks in the arc crust: evidence from Shikanoshima Island (Kyushu, Japan). J. Petrol. 53, 1255-1285. doi: 10.1093/ petrology/egs016

Whalen, J. B., and Hildebrand, R. S. (2019). Trace element discrimination of arc, slab failure, and A-type granitic rocks. Lithos 348-349:105179. doi: 10.1016/j. lithos.2019.105179

Wood, D. A., Gibson, I. L., and Thompson, R. N. (1976). Element mobility during zeolite facies metamorphism of the Tertiary basalts of eastern Iceland. Contrib. Mineral. Petrol. 55, 241-254. doi: 10.1007/bf00371335

Wu, G. (2005). The Yanshanian Orogeny and two kinds of Yanshanides in easterncentral China. Acta Geol. Sin. 79, 507-518. doi: 10.1111/j.1755-6724.2005. tb00917.x

Xu, J. F., Shinjo, R., Defant, M. J., Wang, Q., and Rapp, R. P. (2002). Origin of Mesozoic adakitic intrusive rocks in the Ningzhen area of east China: partial melting of delaminated lower continental crust? Geology 30, 1111-1114.

Yui, T. F., Maki, K., Wang, K. L., Lan, C. Y., Usuki, T., Iizuka, Y., et al. (2012). Hf isotope and REE compositions of zircon from jadeitite (Tone, Japan and north of the Motagua fault, Guatemala): implications on jadeitite genesis and possible protoliths. Eur. J. Min. 24, 263-275. doi: 10.1127/0935-1221/2011/0023-2127

Zheng, Y.-F., Xia, Q.-X., Chen, R.-X., and Gao, X.-Y. (2011). Partial melting, fluid supercriticality and element mobility in ultrahigh-pressure metamorphic rocks during continental collision. Earth Sci. Rev. 107, 342-374. doi: 10.1016/j. earscirev.2011.04.004

Zhou, X., Sun, T., Shen, W., Shu, L., and Niu, Y. (2006). Petrogenesis of Mesozoic granitoids and volcanic rocks in South China: a response to tectonic evolution. Episodes 29, 26-33. doi: 10.18814/epiiugs/2006/v29i1/004

Zhou, X. M., and Li, W. X. (2000). Origin of Late Mesozoic igneous rocks of south-eastern China: implications for lithosphere subduction and underplating of mafic magma. Tectonophysics 326, 269-287. doi: 10.1016/s0040-1951(00) 00120-7

Conflict of Interest: The authors declare that the research was conducted in the absence of any commercial or financial relationships that could be construed as a potential conflict of interest.

Copyright (c) 2020 Suga and Yeh. This is an open-access article distributed under the terms of the Creative Commons Attribution License (CC BY). The use, distribution or reproduction in other forums is permitted, provided the original author(s) and the copyright owner(s) are credited and that the original publication in this journal is cited, in accordance with accepted academic practice. No use, distribution or reproduction is permitted which does not comply with these terms. 